\section{Competitors or Complements: A Meta-analysis of the Effect of Airbnb on Hotel Performance}

\author{
Yang Yang', Marta Nieto García ${ }^{2}$, Giampaolo Viglia ${ }^{2,3}$ (D, \\ and Juan Luis Nicolau ${ }^{4}$ D
}

\begin{abstract}
The rise of peer-to-peer accommodation has challenged the traditional hotel business model. A lingering question is the effect of Airbnb supply on hotel performance. By analyzing 466 estimates from 33 different studies, our results reveal that the negative effect of Airbnb supply on hotel performance is moderate. The meta-regression of effect size recognizes the significant effects of different factors on the strength of the negative effect. In particular, the negative effect is smaller for highend (vs. low-end) hotels, and its magnitude is shrinking over time. Additionally, the detrimental effect is less pronounced for European (vs. Asian) hotels. The study also reports that negative effects are more common in research published in academic journals. The synthesis of the effects across existing studies contributes to a robust and comprehensive understanding of the impact of Airbnb supply on hotel performance.
\end{abstract}

\title{
Keywords
}

meta-analysis, meta-regression, Airbnb supply, hotel performance, publication bias

\section{Introduction}

Peer-to-peer (P2P) networks have radically transformed the way people consume goods and services (Bostman and Rogers 2011; Buhalis et al. 2019; Wang, Asaad, and Filieri 2020). The increasing relevance of $P 2 P$ exchanges is a topic of great interest to scholars and industry professionals. This particular form of exchange is posing threats to traditional businesses across many industries, such as banking, transportation, and hospitality (Botsman 2014). In the lodging industry, Airbnb represents the major P2P accommodation provider, with more than 7 million listings worldwide and a satisfactory level of resilience despite the Covid-19 pandemic (Airbnb 2020a). Between July 2018 and May 2019, Airbnb added more than 1 million listings (Airbnb 2020b), thus raising its share of total accommodation supply (i.e., Airbnb units and hotel rooms). With such exponential growth since its inception in 2008, Airbnb has undoubtedly challenged the traditional hotel industry and set the basis of an agile business model that is more resilient toward potential variations in accommodation demand (Dolnicar 2019).

The disruptive nature of the Airbnb phenomenon has led to a proliferation of studies investigating its effect on hotel performance. Scholars and industry practitioners agree on the pervasive impact of this platform on the accommodation market. Yet extant research remains inconclusive. The majority of studies report a detrimental effect on hotel performance (e.g., Dogru, Hanks, Mody, et al. 2020; Zervas, Proserpio, and Byers 2017), indicating Airbnb as a competitor to the traditional hotel industry. Others, on the contrary, suggest that the effect is negligible (e.g., Borysiewicz 2017; Yang and Mao 2020), or even positive (e.g., Coyle and Yeung 2016; Heo, Blal, and Choi 2019; Strømmen-Bakhtiar and Vinogradov 2019; Aznar et al. 2017). These differential results, coming from a broad range of research settings, data sources, and model specifications, prevent a solid understanding of the actual consequences of the growth of Airbnb and similar P2P platforms on traditional hospitality. To shed light on this issue, the present work offers a meta-analysis

'Department of Tourism and Hospitality Management, Temple University, Philadelphia, PA, USA

${ }^{2}$ Department of Marketing, University of Portsmouth, Portsmouth, England, United Kingdom

${ }^{3}$ Department of Economics and Political Science, University of Aosta Valley, Aosta, Italy

4J. Willard and Alice S. Marriott Professor, Howard Feiertag Department of Hospitality and Tourism Management, Virginia Polytechnic Institute and State University, Pamplin College of Business, Virginia Tech, Blacksburg, VA, USA

\section{Corresponding Author:}

Giampaolo Viglia, Department of Marketing, University of Portsmouth, Richmond Building, Portland Street, Portsmouth, Hampshire POI3DE, United Kingdom.

Email: giampaolo.viglia@port.ac.uk 
that has the broad scope of investigating the influence of both contextual and methodological variables on the impact of Airbnb supply on the performance of traditional hospitality operators. A meta-analysis is defined as "the statistical analysis of a large collection of results from individual studies for the purpose of integrating the findings" (Glass 1976, p. 3). In tourism economics, meta-analyses have been heavily used to synthesize quantitative effects and economic relationships, such as tourism demand elasticities (Peng et al. 2015), effect of world heritage sites on tourism development (Yang, Xue, and Jones 2019), and the tourism-led growth hypothesis (Nunkoo et al. 2020).

In our study, a meta-analysis synthesizes the empirical results from different studies, offering a clear picture of the impact of Airbnb on hotel performance. First, the findings reveal that the overall effect size is negative and very modest $(-0.037)$. However, when taking only the studies that use occupancy rate as the indicator of hotel performance, this negative effect size is slightly larger $(-0.066)$, suggesting that the impact of Airbnb supply on occupancy is more pronounced than the overall effect on hotel performance $(-0.037)$. Second, we recognize a significant level of publication bias in the reported results, which indicates that certain types of results are more likely to be reported. Third, a meta-regression shows a wide array of factors influencing the effect size across estimates, such as research setting, model estimation and specification, and variable measurement and data structure.

This study offers some clear contributions to the current literature on tourism and hospitality management. First and foremost, our study represents a pioneering effort on synthesizing the effect of Airbnb supply on hotel performance based on diverse empirical studies, providing a more nuanced understanding of the Airbnb-hotel performance relationship. Second, we explore the factors moderating this relationship. Most of these factors, such as research context and variable measurement, are typically difficult to be scrutinized in a single empirical study. In light of this, the study provides methodological insights for researchers interested in investigating the Airbnb-hotel performance relationship. Finally, we offer econometric recommendations that could be generalizable to other applied econometric studies in tourism economics.

The remainder of this article is structured as follows. The following two sections present the theoretical background and introduce the key factors shaping the effect of Airbnb supply on hotel performance. The fourth section explains the methodology. The results are discussed in the fifth section. The final section presents the contributions and implications.

\section{Theoretical Background}

\section{P2P Accommodation}

Traditional market exchanges now coexist with alternative forms of consumption consisting of access-based goods or services offered by peers (Bardhi and Eckhardt 2012). These forms of consumption are collectively known as "sharing economy" and have rapidly spread across a number of sectors. Among others, the sharing economy has pervasively transformed the accommodation sector (Karlsson and Dolnicar 2016). In this sector, traditional alternatives (i.e., hotels) now coexist with a different type of accommodation often referred as P2P accommodation. A P2P accommodation unit entails the space that a host rents for short-term stays using a digital platform, thus establishing a room-sharing business in the cyber marketplace (Karlsson et al. 2017). While various terms have been used to refer to these P2P exchanges, our conceptualization of $\mathrm{P} 2 \mathrm{P}$ accommodation emphasizes (1) the platform-mediated nature of the transaction, (2) the necessary monetary exchange, and (3) the broad scope of the accommodation provider that includes both professional and nonprofessional hosts.

Research in tourism and hospitality management has devoted considerable attention to the $\mathrm{P} 2 \mathrm{P}$ accommodation phenomenon. Various streams of literature have emerged that focus on different topics, including (1) the understanding of guests' motivations, attitudes, and behavior (Guttentag et al. 2018; Shuqair, Pinto, and Mattila 2019; So, Oh, and Min 2018; Tussyadiah 2016); (2) the determinants of P2P accommodation demand (Gunter and Önder 2018; Leoni et al. 2020); (3) hosts' behavioral patterns and effective marketing strategies (Gibbs et al. 2018; Nieto García et al. 2019; Wang, Asaad, and Filieri 2020); (4) the impact on international tourism demand (Volgger, Taplin, and Pforr 2019); and (5) societal and economic impacts (e.g., Zervas, Proserpio, and Byers 2017; Dogru, Mody, Suess, et al. 2020). The following section elaborates more on the factors that have hastened the spread of these networks.

\section{Competitive Advantages of P2P Accommodation}

P2P accommodations boast multiple competitive advantages over traditional operators (Dolnicar 2019). First, from the consumer's viewpoint, economic (i.e., lower cost), sustainability (i.e., social and environmental responsibility), and community benefits (i.e., social interactions) are the three main drivers to choose P2P experiences over traditional hotel stays (Tussyadiah 2016). Recent studies also reveal the critical role of home-related benefits (Pera et al. 2019; So, Oh, and Min 2018), and other experiential attributes (Mody, Suess, and Lehto 2019; So, Oh, and Min 2018). Yang, Tan, and $\mathrm{Li}$ (2019) confirm that P2P accommodation users perceive a significantly higher trip value than other tourists. As a result, a new way of travel has emerged (Lee and Kim 2018), with scholars even referring to "Airbnb tourism" (Volgger, Taplin, and Pforr 2019).

Second, another competitive advantage relates to the intrinsic nature of how these networks operate. P2P platform providers advertise private accommodations that are owned by hosts. Therefore, the platform provider can increase 
Table I. The Effect of Airbnb Supply on Hotel Performance Indicators-Main Findings.

\begin{tabular}{|c|c|c|}
\hline Article & Empirical Context & Main Findings \\
\hline $\begin{array}{l}\text { Aznar, Sayeras, Rocafort, } \\
\text { and Galiana (2017) }\end{array}$ & Barcelona (Spain) & Positive correlation between Airbnb supply and hotel's return on equity. \\
\hline Benítez-Aurioles (2019) & Barcelona (Spain) & $\begin{array}{l}\text { Airbnb supply has undermined hotels' occupancy and performance, regardless the } \\
\text { hotel category. }\end{array}$ \\
\hline $\begin{array}{l}\text { Choi, Jung, Ryu, Kim, } \\
\text { and Yoon (20I5) }\end{array}$ & $\begin{array}{l}\text { Seoul, Busan, and } \\
\text { Jeju (Korea) }\end{array}$ & Airbnb supply does not affect hotels' revenue in Korea. \\
\hline $\begin{array}{l}\text { Dogru, Hanks, Mody, } \\
\text { et al. (2020) }\end{array}$ & $\begin{array}{l}\text { London, Paris, } \\
\text { Sydney, and Tokyo }\end{array}$ & $\begin{array}{l}\text { A } 1 \% \text { increase in Airbnb supply decreases hotel RevPAR by between } 0.016 \% \text { and } \\
0.031 \% \text {. }\end{array}$ \\
\hline $\begin{array}{l}\text { Dogru, Hanks, Ozdemir, } \\
\text { et al. (2020) }\end{array}$ & All cities in the US & $\begin{array}{l}\text { Negative impact of Airbnb supply on hotel RevPAR and ADR metrics across } \\
\text { different organizational structures (franchising, managed, and independent hotels). } \\
\text { No significant effect on occupancy. }\end{array}$ \\
\hline $\begin{array}{l}\text { Dogru, Mody, Line, et al. } \\
(2020)\end{array}$ & All cities in the US & $\begin{array}{l}\text { The effect of hotel supply on hotel RevPAR is much larger than that of Airbnb } \\
\text { supply. Airbnb supply adversely affects room prices. The pervasive effects only } \\
\text { appear in states with high hotel supply. }\end{array}$ \\
\hline $\begin{array}{l}\text { Dogru, Mody, and Suess } \\
(2019)\end{array}$ & Ten cities in the US & $\begin{array}{l}\text { A I } \% \text { increase in Airbnb supply decreases hotel RevPAR by } 0.025 \% \text { and ADR by } \\
0.02 \% \text {. The impact on hotel RevPAR varies between } 0.015 \% \text { and } 0.043 \% \text { across } \\
\text { hotel class segments. }\end{array}$ \\
\hline $\begin{array}{l}\text { Heo, Blal, and Choi } \\
(2019)\end{array}$ & Paris (France) & $\begin{array}{l}\text { Different growth and seasonality patterns for Airbnb and hotels. Occupancy has } \\
\text { reached a plateau, ADR is slightly decreasing, and profitability for hosts is dropping. }\end{array}$ \\
\hline $\begin{array}{l}\text { McGowan and Mahon } \\
(2018)\end{array}$ & New York City (US) & $\begin{array}{l}\text { Significant negative effect of Airbnb's entry on hotel revenue, occupancy, and } \\
\text { average daily rate. However, the size of these effects is relatively small. }\end{array}$ \\
\hline $\begin{array}{l}\text { Strømmen-Bakhtiar and } \\
\text { Vinogradov (2019) }\end{array}$ & All cities in Norway & $\begin{array}{l}\text { Airbnb presence has a positive effect on hotel occupancy in Norway. Income per } \\
\text { room is independent of Airbnb activity. }\end{array}$ \\
\hline Xie and Kwok (2017) & Austin, Texas (US) & $\begin{array}{l}\text { Airbnb supply negatively affects nearby hotels' performance. The relationship is } \\
\text { moderated by price difference (hotel - Airbnb) and price dispersion. }\end{array}$ \\
\hline Yang and Mao (2020) & $\begin{array}{l}\text { Houston, Texas } \\
\text { (US) }\end{array}$ & $\begin{array}{l}\text { The effect of location advantage on lodging performance is stronger for urban hotels } \\
\text { than Airbnb units. The findings do not suggest a direct competition between urban } \\
\text { hotels and Airbnb units. }\end{array}$ \\
\hline $\begin{array}{l}\text { Zervas, Proserpio, and } \\
\text { Byers (2017) }\end{array}$ & $\begin{array}{l}\text { All cities in Texas } \\
\text { (US) }\end{array}$ & $\begin{array}{l}\text { The negative impact of Airbnb supply on hotel revenue ranges between } 8 \% \text { and } 10 \% \text {. } \\
\text { Low-price hotels and those that do not cater to business travelers are the most } \\
\text { affected. }\end{array}$ \\
\hline
\end{tabular}

short-term rental capacity rapidly at a minimal marginal cost (Zervas, Proserpio, and Byers 2017). Previous research has also noted the advantage in terms of leveraging an augmented set of locations-hosts' properties are more geographically disperse (Gutiérrez et al. 2017). Some types of Airbnb properties can be found in areas with a limited hotel supply (Yang and Mao 2019). Lastly, compared with traditional operators, P2P platform providers have access to accommodations that are unique in their design and features, making them especially suitable for a tailored offer that satisfies the needs of niche markets (Dolnicar 2018). In light of these arguments, it becomes evident that this alternative marketplace is often in direct competition with certain types of hotels.

\section{Effects of P2P Accommodation Supply on Hotel Performance}

Of particular interest to the hotel industry is assessing the impact of P2P accommodation supply on key hotel performance indicators (Dogru, Hanks, Mody, et al. 2020; Dogru, Hanks, Ozdemir, et al. 2020). The P2P accommodation market has witnessed a rapid expansion, with several platforms operating in this marketplace (i.e., Homeaway, HouseTrip, HomeToGo). Airbnb, with more than 7 million listings worldwide (Airbnb 2020), has become the dominant player. As a result, Airbnb has been used as the empirical context in many academic studies assessing the impact of P2P accommodation on hotel performance. The majority of studies suggest that the increased Airbnb supply has generated a detrimental effect on hotel performance (e.g., Byers et al. 2013; Dogru, Mody, and Suess 2019; McGowan and Mahon 2018), with the argument that increased supply has diluted the demand of traditional hotel accommodation (Zervas, Proserpio, and Byers 2017). However, the competitive dynamics seem to differ across destinations. For instance, in Paris, Heo, Blal, and Choi (2019) find a nonsignificant effect of P2P accommodation on hotel performance. Table 1 presents a synthesis of the main findings published in peerreviewed journal articles. The summary table suggests that the academic knowledge on the topic remains very fragmented. This could be explained by the wide variety of research approaches, research designs (e.g., research period, research unit, and location), and methodological techniques 


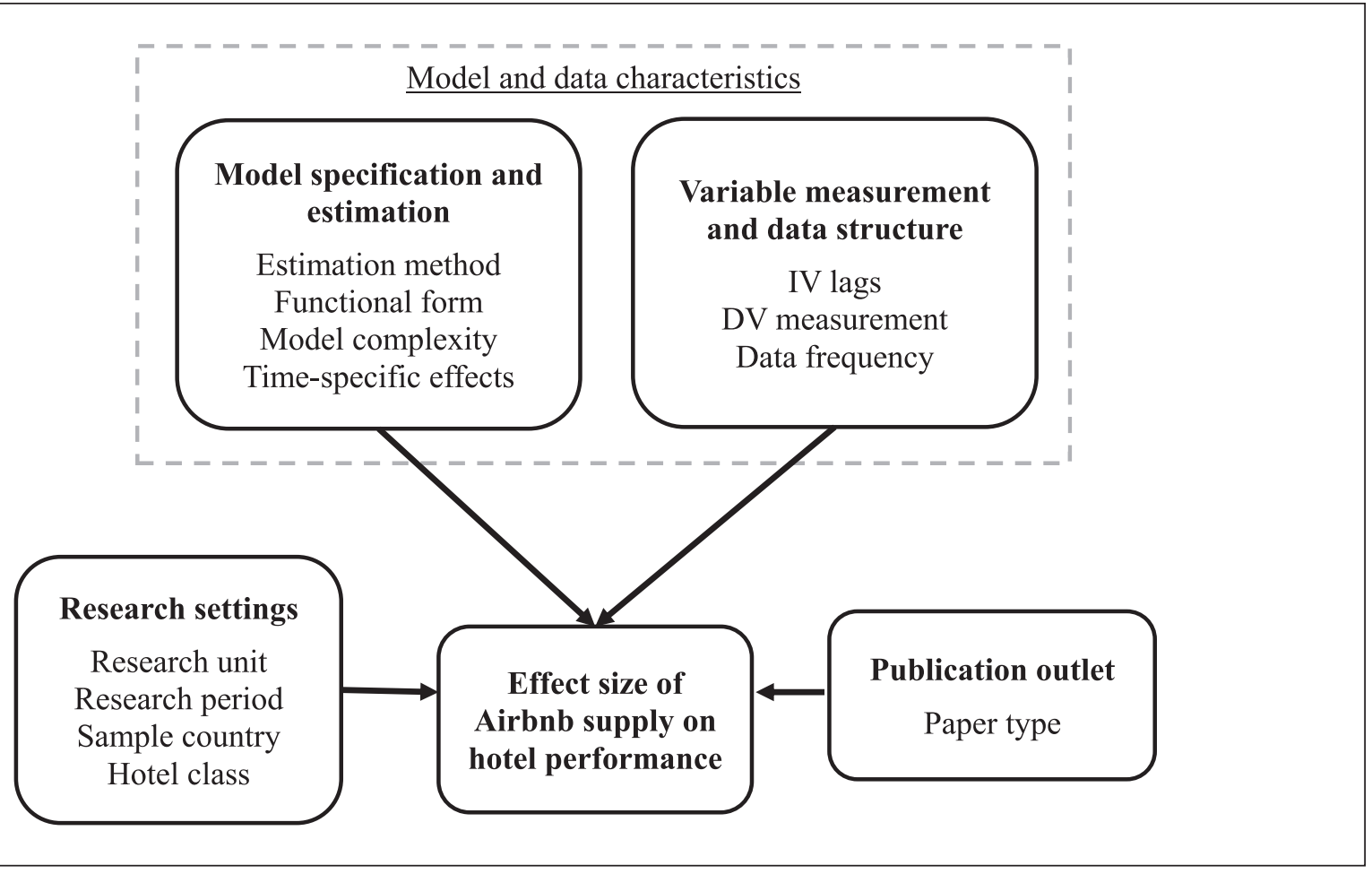

Figure I. Conceptual framework.

(e.g., model specification, variable operationalization, and estimation strategies).

\section{Conceptual Framework}

Figure 1 presents the conceptual model of the meta-analysis, showing the factors that shape the effect size of Airbnb supply on hotel performance. The model comprises a list of factors that come from the literature and are grouped into four categories (i.e., research settings, model specification and estimation, variable measurement and data structure, and publication outlet). These categories emerge from common practice in previous meta-analyses in tourism and marketing research (e.g., Yang, Xue, and Jones 2019; You, Vadakkepatt, and Joshi 2015).

\section{Research Settings}

Research unit. The research unit plays an important role in determining substitution patterns between hotels and Airbnb properties. City-level demand trends affect both Airbnb supply and hotel revenue (Zervas, Proserpio, and Byers 2017). When using a broader unit of analysis (e.g., regional aggregated data) instead of individual property data, the effect of Airbnb supply on hotel performance may dilute or exaggerate because of the potential impact of other factors. Following this argument, our study proposes that the effect size will be different between studies using the property-level data and those using regional aggregated data.
Research period. Since its entry into the accommodation market, Airbnb has undergone exponential growth. The platform has become increasingly popular across countries over the last five years (Airbnb 2020). This increased awareness may result in a more pronounced detrimental impact on hotel performance in later periods. On the other hand, the negative effect could diminish over time as the hotel industry became more prepared for the sharing economy. Low-end hotels can compete on prices, whereas high-end ones can invest in service quality (Chang and Sokol 2020). In later periods, the industry is also witnessing various types of restrictions and regulations on home-sharing services imposed by the local governments (Nieuwland and Van Melik 2020; Falk and Yang 2020). Therefore, we expect that the research period will influence the effect size of the Airbnb-hotel performance relationship.

Sample country. Market conditions (e.g., regulations) or cultural aspects in an area might affect the impact Airbnb has on hotel performance. This impact might be weaker in areas where hotel supply exceeds demand (Dogru, Mody, Line, et al. 2020). Similarly, the cultural background may affect the willingness to use P2P stays as a substitute for traditional hotel experiences. For instance, Chinese notions of hospitality differ culturally from those of Western countries (Cheng and Zhang 2019). In China, homes are not places to share with strangers; as a result, Airbnb has not substantially penetrated this market. Instead, alternative P2P networks had better catered to the needs of Chinese consumers (Xiang and 
Dolnicar 2018). Following these arguments, we expect that the effect of Airbnb supply on hotel performance will vary across different geographic regions.

Hotel class. While high-end hotels rely on high-quality service and luxury features, low-end hotels mainly focus on guests' functional needs. The importance that consumers attribute to each hotel feature differs by hotel class (Mattila 2007; Rhee and Yang 2015). Therefore, Airbnb may not be an ideal substitute for every consumer. It would be more attractive for consumers with budget restrictions and less attractive for travelers looking for outstanding service or specialized features (e.g., business travelers). If this is the case, the negative effect of Airbnb on hotel performance should be higher for low-end hotels than high-end hotels.

\section{Model Specification and Estimation}

Estimation method. The majority of studies investigating the Airbnb-hotel performance relationship rely on panel data estimation, looking both at cross-sectional and longitudinal effects. Among the latter ones, some studies adopt estimation methods based on maximum likelihood techniques, such as autoregressive distributed lag model (Dogru, Hanks, Ozdemir, et al. 2020) or augmented mean group (Coyle and Yeung 2016), while others employ modified least-squares techniques, such as the fixed effects model (Zervas, Proserpio, and Byers 2017) or panel dynamic ordinary least squares (Coyle and Yeung 2016). Studies also differ in the estimation method of standard errors, with some of them using robust standard errors to obtain unbiased estimates under heteroscedasticity (e.g., Kim and Lee 2019). While this approach is appropriate with large samples, its use may result in inefficient estimates in case of homoscedasticity. We, therefore, propose that the effect size differs between studies using robust standard errors and those that do not.

Functional form. The functional form adopted in a study may also affect the effect size. Previous works have used different types of functional forms. Some of them transform the values of both dependent and independent variables into their logarithmic $(\log )$ values $(\log -\log$; e.g., Choi et al. 2015). Others only transform in log either the values of the dependent variable (log-level; e.g., Borysiewicz 2017) or the values of the independent variable (level-log; e.g., Dogru, Mody, and Suess 2017). Some studies leave both variables untransformed (level-level; e.g., Benítez-Aurioles 2019). Therefore, we examine whether the transformation of the dependent variable, independent variables, or both affects the effect size.

Model complexity. Our study also tests whether the number of independent variables included in the model has an impact on the effect size. Omitting variables from the estimation model could potentially lead to biased results (i.e., omitted variable bias). Thus, we include the number of independent variables as a measure of model complexity in our metaanalysis. A larger number of theoretically relevant independent variables leads to a more accurate specification of the model, which may influence the effect size.

Time-specific effects. The effect size may vary across studies depending on whether the models capture time-specific effects. The time-specific effects account for variation that comes from events or trends linked to the specific period. In our work, we investigate whether the inclusion of timespecific effects in the econometric model leads to different effect sizes. We argue that including time-specific effects improves the specification of the model by alleviating the omitted variable issue and therefore affects the effect size.

\section{Variable measurement and data structure}

Independent variable lags. The inclusion of lagged independent variables in the estimation model has been a common strategy to address reverse causality and other endogeneity issues. Despite the criticism of the use of lagged independent variables for identification purposes (Bellemare, Masaki, and Pepinsky 2017), many studies still rely on this strategy. One fundamental premise is that it may take time for the hotel market to respond to the supply change of Airbnb units, and the use of lagged variables (LV) is able to capture this delay (Xie and Kwok 2017). Therefore, we test whether the use of independent variable lags affects the resulting estimates.

Dependent variable (DV) measurement. The most common metrics of hotel performance are average daily rate, occupancy rate, and revenue per available room (RevPAR). While several studies report a detrimental effect of Airbnb supply on hotel total revenues and RevPAR (Xie and Kwok 2017; Zervas, Proserpio, and Byers 2017), the impact on occupancy has offered mixed results (e.g., Benítez-Aurioles 2019; Dogru, Hanks, Ozdemir, et al. 2020). Thus, we analyze the influence of using different performance measures (i.e., average daily rate, occupancy, RevPAR, and others) on the effect size.

Data frequency. Similar to unit aggregation, the temporal aggregation of data in empirical models may play a role in diluting variations of hotel performance (You, Vadakkepatt, and Joshi 2015). Lower data frequency might result in a diluted effect. This meta-analysis tests whether the data frequency (e.g., monthly, quarterly, yearly) affects the effect size.

\section{Publication Outlet}

The publication outlet has been frequently included as a key parameter in meta-analyses that explore contrasting results (e.g., You, Vadakkepatt, and Joshi 2015). A 
significant effect of this parameter reveals the existence of publication bias, which can be defined as "the selective publication of studies with a particular outcome, generally, those which are statistically significant, at the expense of null studies" (Ferguson and Brannick 2012, p. 120). Some publication outlets, such as academic journals, require double-blind reviews. Therefore, the authors may be motivated to present more favorable estimates to reviewers. Specifically, we expect highly significant effects in academic journal articles while less or nonsignificant effects in studies from other outlets that do not undergo a very selective peer-review process (e.g., working papers and conference papers).

\section{Methodology}

\section{Study Collection and Data Coding}

Existing studies on the effect of Airbnb on hotel performance were collected through an extensive search on databases, including Google Scholar, EBSCO Hospitality \& Tourism Complete, and ProQuest Dissertations. The search only included studies written in English. The keywords used for the search included hotel performance, Airbnb, Airbnb supply, hotel RevPAR, hotel occupancy, and hotel rates. Additional articles were gathered after further crossreferencing. The empirical studies should use an applied econometric method to investigate the impact of Airbnb supply (as an independent variable) on hotel performance (as a dependent variable) in a double-log, semi-log, or level-level functional form. The study collection ran from October 2019 until January 2021, following the general guidelines of literature search for meta-analysis (Stanley and Doucouliagos, 2012). We then screened the studies according to several criteria:

1. We excluded the articles with incomplete information, especially those without clear information on the statistics related to the effect size, such as the number of observations, standard errors, or $t$ statistics of regression coefficients (e.g., Dogru, Mody, and Suess 2017).

2. We excluded the articles in which the dependent variable and independent variables used different orders of differencing (e.g., Mohamad 2016).

3. We removed the studies including both current and historical Airbnb supply measures in a single model (e.g., Apergis, Hayat, and Saeed 2020).

4. We removed studies using Airbnb occupancy rate to measure the Airbnb supply effect (e.g., Ginindza and Tichaawa 2019).

5. We excluded the studies using other types of homesharing services, like Xiaozhu and Tujia, in China (e.g., Chen, Wei, and Xie 2019). By applying all the criteria, we ended up with a total of 33 studies.
The final meta-sample of 33 studies includes journal articles (17), dissertations and theses (6), working papers (6), and conference papers (4). Most of these studies incorporate several model specifications, and some of them conduct different analyses using different subsamples. Therefore, the researchers coded the estimates for each model specification and subsample from each study. Two coders undertook the coding process and discussed any inconsistency until reaching a consensus.

We chose partial correlation $r$ as the effect size reflecting the impact of Airbnb supply on hotel performance. The partial correlation measures the association between two variables after controlling for other variables, and the coefficient is unit-free, which allows for interstudy comparison based on a consistent measure (Djankov and Murrell 2002). The partial correlation has been frequently adopted in meta-analyses of applied econometrics (Stanley, Doucouliagos, and Steel 2018; Havranek, Irsova, and Zeynalova 2018), and in particular, in tourism research (Yang, Xue, and Jones 2019; Nunkoo et al. 2020). The partial correlation $r$ is calculated as

$$
r=\frac{t}{\sqrt{t^{2}+d f}}
$$

where $t$ is the reported $t$ statistic of estimated coefficient in the econometric model and $d f$ represents the degree of freedom of the model. The standard error is $\sqrt{\left(1-r^{2}\right) / d f}$. We did not conduct Fisher's $z$ transformation because of the slight bias associated with the transformation (Schulze 2004). For studies failing to report relevant information of $t$ statistics, we used the midpoint of significance range as indicated in the estimation table (Greenberg, Michalopoulos, and Robins 2003); for example, corresponding $t$ statistic at a $p$-value of 0.03 is used for estimates significant at the 0.05 level while $t$ statistic at a $p$-value of 0.005 is used for estimates significant at the 0.01 level. At the same time, we also coded other relevant information about the estimate and research, such as the research setting, sample size, research period, model specification, variable operationalization, control variables used, estimation methods, and publication outlet. By doing so, we were able to unveil factors contributing to the heterogeneity across different empirical studies in the meta-analysis sample. In particular, we coded multiple effect sizes within a single study to improve the efficiency from the expanded sample size and extra within-study variation for meta-regression (Melo, Graham, and Noland 2009). To reduce the potential coding bias, we did not code estimates based on the interaction terms with an Airbnb supply measure. A total set of 466 estimates is finally used to perform the meta-analysis.

\section{Meta-analysis Methods}

In the first step of meta-analysis, we synchronize the results from past studies by combining the effect size. In a meta-analysis, both fixed effects and random effects can be used to 
yield a weighted average of effect size (Ringquist 2013). Statistics, such as $I^{2}$ and the $Q$ statistic of the test of homogeneity, are used to gauge which method is more appropriate to generate the combined effect size (Schmidt and Hunter 2014). However, some adjustments are necessary for investigating the presence of publication bias (see Moldes and $\mathrm{Ku} 2020$ ). Two sources of publication bias exist. Type I publication bias occurs when a strong preference exists for certain types of results. In the context of the Airbnb-hotel performance relationship, the negative coefficient can be more accepted with the existing theories, leaving some authors and reviewers treating the positive coefficient suspicious. A funnel plot can be used to detect the presence of type I bias, and a nonparametric "trim-and-fill" method is used to impute the data and alleviate this bias (Duval and Tweedie 2000). The method iteratively estimates missing studies due to publication bias and imputes the effect sizes and standard errors. After that, the original and imputed effect sizes are pooled to generate the combined effect size. Type II publication bias exists when researchers are more (or less) inclined to report significant results (Stanley 2005), and a Galbraith plot can detect this bias.

The study relies on a meta-regression to examine factors shaping the effect size. Meta-regression analysis (MRA) is a multivariate empirical analysis that uses regression techniques to uncover the causes of variation among reported regression estimates (Stanley and Doucouliagos 2012). In the presence of heterogeneity between studies, an MRA is appropriate to explain the differences between the studies (Van Houwelingen, Arends, and Stijnen 2002, p. 607). Equation 2 presents the analytical model.

$$
r_{i}=\beta_{0}+\gamma S E\left(r_{i}\right)+\sum_{j=1}^{k} \beta_{j} Z_{j}+\varepsilon_{i}
$$

where $r$ is the partial correlation coefficient, $Z$ represents the set of $k$ explanatory variables explaining the different partial correlation coefficients, $S E(r)$ is the standard error of partial correlation coefficient, and $\varepsilon$ is the error term. Interestingly, when no explanatory variables were included, the coefficient $\gamma$ can be used to test the presence of publication bias (Stanley and Doucouliagos 2012). As the ordinary least squares (OLS) estimation of Equation 2 can lead to the heteroscedasticity issue, a weighted least squares (WLS) method is used to correct for this issue (Stanley and Doucouliagos 2016; Stanley, Doucouliagos, and Steel 2018). The WLS method applies the inverse of squared standard error $S E(r)$ as the weight. According to Stanley and Doucouliagos (2016), WLS estimation outperforms random/mixed effects meta-regression in the presence of publication bias and is superior to fixed effects meta-regression in most applications.
According to the research framework in Figure 1, we include a set of explanatory variables to capture the difference of research settings, model estimation and specification, variable measurement and data structure, and publication outlet across studies. Table 2 shows the coding scheme and descriptions of the variables in the meta-analysis. Table 3 presents the descriptive statistics of dependent and independent variables in the regression. The mean value of $r$, the effect size, is -0.042 . The average year of data observation is around 2012. In the sample, $32.6 \%$ of effect sizes were collected from property data (property_data), 55.8\% were estimated using a robust standard error (robust_error), and $62.0 \%$ were calibrated with a log-log functional form $(\log \log )$. Moreover, $76.0 \%$ of effect sizes were obtained from studies embracing the time-specific effects in the panel data econometric model (timedummy), and 3.6\% were collected from models with a lagged Airbnb-supply variable (indep_lag). Most studies used high-frequency data, and $82.2 \%$ of effect sizes were monthly/daily-based (high frequency). Effect sizes from journal articles account for $54.3 \%$ of the sample (journal_article), while others were collected from thesis/dissertation, conference papers, and working papers. Regarding geography of the sample, 39.06\% of effect sizes were from studies using a North American sample, followed by European sample and Asian sample, which account for $31.97 \%$ and $19.74 \%$, respectively. Most studies did not split the sample by hotel classes, and only around one-third effect sizes are hotel class-specific. Lastly, RevPAR was found to be a slightly more popular measure of performance than the average daily rate (ADR) and occupancy in the sample. We also provide the variance inflation factor (VIF) of each variable, and all of them are below 5.0, indicating the absence of multicollinearity issues in our sample.

\section{Results}

\section{Publication Bias and Pooled Effect Size}

Figure 2 presents the graphic summary of 466 coded effect sizes from 33 empirical studies. For each study, the box plot shows the distribution of effect sizes within the study. The earliest study in the sample dated back to 2013, with the latest published in 2020. A considerable variation can be observed across studies. For instance, although most effect sizes were negative, we can observe some positive effect sizes. In a more extreme case, some studies have a positive median effect size based on the box plot.

Figure 3 presents the funnel plot and the Galbraith plot to identify the possible type I and II publication bias in the sample, respectively. The funnel plot is a scatterplot with effect size as a horizontal axis against its standard error. In the absence of publication bias, the plot should be symmetric with an inverted funnel-shaped (Stanley and Doucouliagos 
Table 2. Description of Independent Variables and Coding Scheme.

\begin{tabular}{|c|c|c|}
\hline Variable & Label & Coding Scheme \\
\hline \multicolumn{3}{|l|}{ Research settings } \\
\hline Research unit & property_data & $\begin{array}{l}\mathrm{I}=\text { data obtained from each single hotel property; } 0=\text { aggregated data from } \\
\text { multiple hotel properties }\end{array}$ \\
\hline Research period & midyear & midpoint of research period in the sample (year) \\
\hline Sample country & geography & $\mathrm{I}=$ Asia (benchmark), $2=$ Europe, $3=$ Global, $4=$ North America, and $5=$ Africa \\
\hline Hotel class & class_hotel & $\mathrm{I}=$ all, $2=$ low-end (benchmark), $3=$ midscale, and $4=$ high-end \\
\hline \multicolumn{3}{|c|}{ Model estimation and specification } \\
\hline Model estimation & robust_error & $\mathrm{I}=$ robust standard errors used in the model estimation; $0=$ others \\
\hline Functional form & $\log \_\log$ & $\mathrm{I}=\log -\log$ functional form in the model; $0=$ others \\
\hline Model complexity & Inindep & log of the number of independent variables used in the model \\
\hline Time-specific effects & timedummy & $\mathrm{I}=$ year-specific effects included in the econometric model; $0=$ others \\
\hline \multicolumn{3}{|c|}{ Variable measurement and data structure } \\
\hline IV lags & indep_lag & $\mathrm{I}=$ use of lagged Airbnb supply as the independent variable, $0=$ others \\
\hline DV measurement & DV & $\mathrm{I}=\mathrm{ADR}$ (benchmark), $2=$ occupancy, $3=$ RevPAR, and $4=$ others \\
\hline Data frequency & high_frequency & $\mathrm{I}=$ monthly/daily data; $0=$ yearly/biyearly/quarterly data in the model \\
\hline \multicolumn{3}{|l|}{ Publication outlet } \\
\hline Journal article & journal_article & $\begin{array}{l}\text { I = study published as a journal article; } 0=\text { other publication outlets (e.g., thesis/ } \\
\text { dissertation, working paper, conference paper) }\end{array}$ \\
\hline
\end{tabular}

Table 3. Descriptive Statistics of Variables in Meta-Regression.

\begin{tabular}{|c|c|c|c|c|}
\hline Variable & Observations & Mean & Standard Deviation & VIF \\
\hline$r$ & 466 & -0.042 & 0.175 & \\
\hline$S E(r)$ & 466 & 0.044 & 0.052 & 3.47 \\
\hline property_data & 466 & 0.326 & 0.469 & 3.47 \\
\hline midyear & 466 & 2012.120 & 2.545 & 2.46 \\
\hline robust_error & 466 & 0.558 & 0.497 & 3.41 \\
\hline $\log \_\log$ & 466 & 0.620 & 0.486 & 1.98 \\
\hline Inindep & 466 & 1.848 & 0.618 & 2.56 \\
\hline timedummy & 466 & 0.760 & 0.428 & 2.14 \\
\hline indep_lag & 466 & 0.036 & 0.188 & 1.19 \\
\hline high_frequency & 466 & 0.822 & 0.383 & 1.81 \\
\hline \multirow[t]{2}{*}{ journal_article } & 466 & 0.543 & 0.499 & 2.94 \\
\hline & Frequency & Percentage & Cumulative Percentage & \\
\hline geography $=$ Asia & 92 & 19.74 & 19.74 & \\
\hline geography $=$ Europe & 149 & 31.97 & 51.72 & 3.03 \\
\hline geography $=$ Global & 24 & 5.15 & 56.87 & 2.03 \\
\hline geography $=$ North America & 182 & 39.06 & 95.92 & 3.84 \\
\hline geography $=$ Africa & 19 & 4.08 & 100.00 & 2.98 \\
\hline class_hotel = all & 289 & 62.02 & 62.02 & 3.33 \\
\hline class_hotel $=$ low end & 46 & 9.87 & 71.89 & \\
\hline class_hotel = mid-scale & 44 & 9.44 & 81.33 & 1.97 \\
\hline class_hotel $=$ high-end & 87 & 18.67 & 100.00 & 2.54 \\
\hline$D V=A D R$ & 109 & 23.39 & 23.39 & \\
\hline$D V=$ occupancy & 114 & 24.46 & 47.85 & 1.92 \\
\hline$D V=R e v P A R$ & 123 & 26.39 & 74.25 & 1.91 \\
\hline$D V=$ Others & 120 & 25.75 & 100.00 & 1.92 \\
\hline
\end{tabular}

Note: VIF $=$ variance inflation factor.

2010). As shown in Figure 3, many points fall out of the inverted funnel (pseudo 95\% CI) area of the funnel plot, and the plot looks asymmetric as indicated by the heavier left portion. Therefore, the funnel plot indicates the presence of type I publication bias. We further run a meta-regression to test the presence of publication bias with $S E(r)$ as the only 


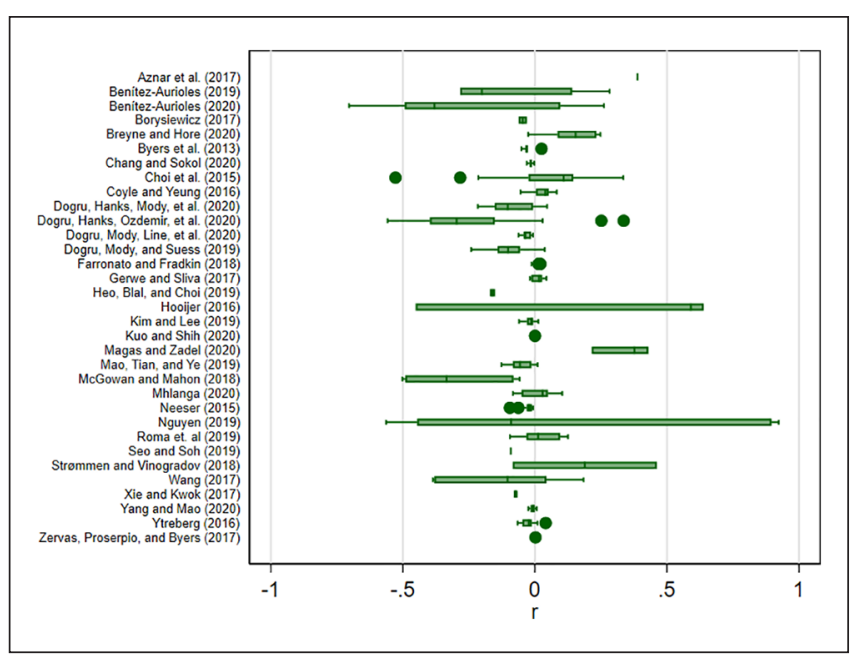

Figure 2. Summary of effect sizes from different studies.

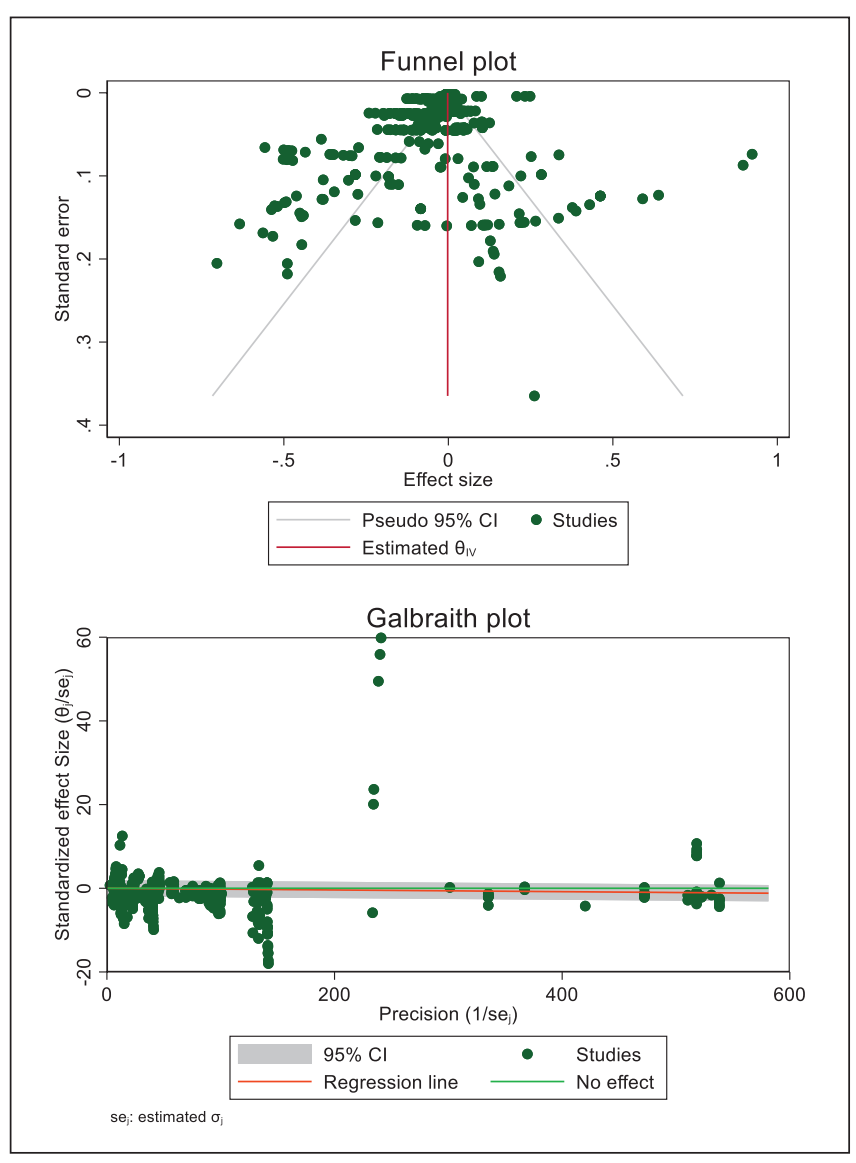

Figure 3. Funnel plot and Galbraith plot for publication bias analysis.

independent variable (model 1 in Table 4), and the coefficient of $S E(r)$ is estimated to be negative and significant, confirming the presence of this bias (Stanley and Doucouliagos 2012). The Galbraith plot has the inverse of standard error (precision) as the horizontal axis against the associated standardized effect size. As shown in Figure 3, more than $10 \%$ of observations fall out of the $95 \% \mathrm{CI}$ region parallel to the regression line, suggesting the presence of type II publication bias.

In the presence of publication bias, we perform a trimand-fill analysis to pool the effect size. By doing that, we impute the data to make the effect sizes symmetric. $I^{2}$ is $99.66 \%$, and the $Q$ statistic of the test of homogeneity is $8094.66(d f=365)$, indicating the strong heterogeneity across estimates (Schmidt and Hunter 2014). Therefore, random effects analysis is used to pool the results. Table 5 presents the results of the combined effects. It shows that the overall effect size is -0.037 , and it is statistically significant at the 0.05 level. As suggested by Doucouliagos (2011), a combined effect of partial correlations lower than 0.07 indicates a small effect size. Therefore, the result shows that the effect of Airbnb supply on hotel performance is very moderate and close to zero. Table 5 also presents the results of the subgroup analysis. Across different geographical regions, the negative effect is more sizable in North America than in Asia, Europe, and Africa. The combined effect size is not statistically significant at the $95 \%$ level in the subsamples of European and African data. Across different hotel classes, the negative effect size is most substantial for low-end hotels. For studies using different hotel performance measures, the negative effect size is larger for the occupancy subgroup than ADR and RevPAR subgroups. The combined effect size is statistically insignificant for other performance measures (DV = Others).

Furthermore, we noticed that the effect size from published journal articles (journal_article $=1$ ) is significantly different from others (journal_article $=0$ ) as the 95\% CI of the two subgroups does not overlap. Lastly, the combined negative effect size is slightly more pronounced in the early research period (midyear $\leq 2013$ ) than the late one. Figure 4 further visualizes these combined effects and the associated $95 \% \mathrm{CI}$.

\section{Meta-regression}

Table 4 presents the estimation results of the WLS regression. Because the pooled effect size is negative, a negative coefficient in meta-regression indicates that the negative effect of Airbnb supply on hotel performance gets stronger along with the increase in the corresponding independent variable. Model 1 includes only $S E(r)$, the standard error of effect size, to test the publication bias. The coefficient of $S E(r)$ is estimated to be negative and significant, which indicates that a smaller partial correlation coefficient is associated with a higher precision of the estimates. This result indicates the presence of significant publication bias and supports the results from the funnel plot. In Model 2, we include all proposed variables explaining the effect size as explanatory variables of meta-regression, and the sample 
Table 4. Meta-regression Results Based on WLS Estimation.

\begin{tabular}{|c|c|c|c|c|c|c|}
\hline & Model I & Model 2 & Model 3 & Model 4 & Model 5 & Model 6 \\
\hline & All & All & ADR & Occupancy & RevPAR & Others \\
\hline Variables & WLS & WLS & WLS & WLS & WLS & WLS \\
\hline$S E(r)$ & $\begin{array}{l}-1.667 * * * \\
(0.557)\end{array}$ & $\begin{array}{l}-3.368 * * * \\
(0.908)\end{array}$ & $\begin{array}{l}-4.125 * * * \\
(0.956)\end{array}$ & $\begin{array}{l}-2.626 * * * \\
(0.762)\end{array}$ & $\begin{array}{l}-3.142 * * * \\
(0.743)\end{array}$ & $\begin{array}{l}-1.685 \\
(2.170)\end{array}$ \\
\hline property_data & & $\begin{array}{l}-0.001 \\
(0.022)\end{array}$ & $\begin{array}{l}-0.037 \\
(0.029)\end{array}$ & $\begin{array}{l}-0.064 \\
(0.047)\end{array}$ & $\begin{array}{c}0.076 \\
(0.098)\end{array}$ & $\begin{array}{l}-0.088 \\
(0.098)\end{array}$ \\
\hline midyear & & $\begin{array}{l}0.008 * * * \\
(0.003)\end{array}$ & $\begin{array}{c}-0.002 \\
(0.005)\end{array}$ & $\begin{array}{l}0.029 * * * \\
(0.008)\end{array}$ & $\begin{array}{c}0.013^{*} \\
(0.007)\end{array}$ & $\begin{array}{c}0.052 \\
(0.061)\end{array}$ \\
\hline geography $=$ Europe & & $\begin{array}{l}0.060 * * \\
(0.025)\end{array}$ & $\begin{array}{l}0.122^{* * *} \\
(0.037)\end{array}$ & $\begin{array}{l}-0.157 \\
(0.107)\end{array}$ & $\begin{array}{c}0.134 \\
(0.092)\end{array}$ & $\begin{array}{l}0.101 \\
(0.110)\end{array}$ \\
\hline geography = Global & & $\begin{array}{c}0.046 \\
(0.05 I)\end{array}$ & $\begin{array}{l}0.274 * * * \\
(0.057)\end{array}$ & $\begin{array}{l}-0.045 \\
(0.041)\end{array}$ & $\begin{array}{l}0.205^{* * * *} \\
(0.041)\end{array}$ & \\
\hline $\begin{array}{l}\text { geography }=\text { North } \\
\text { America }\end{array}$ & & $\begin{array}{l}0.010 \\
(0.022)\end{array}$ & $\begin{array}{l}0.086^{* *} \\
(0.04 I)\end{array}$ & $\begin{array}{l}-0.071 \\
(0.043)\end{array}$ & $\begin{array}{l}0.123 * * * \\
(0.033)\end{array}$ & $\begin{array}{l}-0.026 \\
(0.046)\end{array}$ \\
\hline geography = Africa & & $\begin{array}{l}0.07 I^{* *} \\
(0.029)\end{array}$ & & & $\begin{array}{c}0.113 \\
(0.082)\end{array}$ & \\
\hline class_hotel = all & & $\begin{array}{l}0.016 \\
(0.011)\end{array}$ & $\begin{array}{c}0.027^{*} \\
(0.015)\end{array}$ & $\begin{array}{c}0.003 \\
(0.008)\end{array}$ & $\begin{array}{c}0.015 \\
(0.010)\end{array}$ & $\begin{array}{l}-0.025 \\
(0.025)\end{array}$ \\
\hline $\begin{array}{l}\text { class_hotel = mid- } \\
\text { scale }\end{array}$ & & $\begin{array}{c}-0.022 \\
(0.036)\end{array}$ & $\begin{array}{c}0.005 \\
(0.026)\end{array}$ & $\begin{array}{c}0.024^{*} \\
(0.013)\end{array}$ & $\begin{array}{c}-0.037 \\
(0.049)\end{array}$ & $\begin{array}{c}0.011 \\
(0.013)\end{array}$ \\
\hline $\begin{array}{l}\text { class_hotel = high- } \\
\text { end }\end{array}$ & & $\begin{array}{l}0.017 * * * \\
(0.006)\end{array}$ & $\begin{array}{l}0.033^{* *} \\
(0.012)\end{array}$ & $\begin{array}{c}0.001 \\
(0.005)\end{array}$ & $\begin{array}{l}0.016^{* * * *} \\
(0.005)\end{array}$ & $\begin{array}{l}-0.008 \\
(0.018)\end{array}$ \\
\hline robust_error & & $\begin{array}{l}-0.024 \\
(0.026)\end{array}$ & $\begin{array}{c}0.002 \\
(0.026)\end{array}$ & $\begin{array}{l}-0.045 * * \\
(0.020)\end{array}$ & $\begin{array}{l}-0.045 \\
(0.061)\end{array}$ & $\begin{array}{l}-0.102 \\
(0.066)\end{array}$ \\
\hline log_log & & $\begin{array}{l}-0.007 \\
(0.011)\end{array}$ & $\begin{array}{c}-0.113^{*} \\
(0.061)\end{array}$ & $\begin{array}{l}0.205^{* *} \\
(0.089)\end{array}$ & $\begin{array}{l}-0.048 \\
(0.092)\end{array}$ & $\begin{array}{l}0.289 \\
(0.287)\end{array}$ \\
\hline Inindep & & $\begin{array}{c}0.005 \\
(0.012)\end{array}$ & $\begin{array}{l}0.041^{* * *} \\
(0.014)\end{array}$ & $\begin{array}{c}-0.019 * \\
(0.010)\end{array}$ & $\begin{array}{l}-0.011 \\
(0.008)\end{array}$ & $\begin{array}{l}-0.017 \\
(0.013)\end{array}$ \\
\hline timedummy & & $\begin{array}{l}-0.013 * * \\
(0.006)\end{array}$ & $\begin{array}{l}0.007 \\
(0.021)\end{array}$ & $\begin{array}{l}-0.053 \\
(0.040)\end{array}$ & $\begin{array}{l}-0.013 * * * \\
(0.004)\end{array}$ & $\begin{array}{c}0.010 \\
(0.021)\end{array}$ \\
\hline indep_lag & & $\begin{array}{l}-0.029 * * * \\
(0.011)\end{array}$ & $\begin{array}{l}0.010 \\
(0.017)\end{array}$ & $\begin{array}{l}-0.016 \\
(0.021)\end{array}$ & $\begin{array}{l}-0.070 \\
(0.052)\end{array}$ & $\begin{array}{l}-0.020 * * * \\
(0.004)\end{array}$ \\
\hline$D V=$ occupancy & & $\begin{array}{l}-0.011 \\
(0.011)\end{array}$ & & & & \\
\hline$D V=\operatorname{RevPAR}$ & & $\begin{array}{c}0.001 \\
(0.006)\end{array}$ & & & & \\
\hline$D V=$ others & & $\begin{array}{l}-0.007 \\
(0.007)\end{array}$ & & & & \\
\hline high_frequency & & $\begin{array}{l}-0.038^{* *} \\
(0.018)\end{array}$ & $\begin{array}{l}-0.107 \\
(0.064)\end{array}$ & $\begin{array}{c}0.165^{*} \\
(0.090)\end{array}$ & $\begin{array}{c}-0.035^{*} \\
(0.018)\end{array}$ & $\begin{array}{l}-0.038 \\
(0.060)\end{array}$ \\
\hline journal_article & & $\begin{array}{c}0.028 \\
(0.021)\end{array}$ & $\begin{array}{l}-0.006 \\
(0.017)\end{array}$ & $\begin{array}{l}-0.012 \\
(0.021)\end{array}$ & $\begin{array}{c}-0.054 \\
(0.072)\end{array}$ & $\begin{array}{c}0.264 \\
(0.239)\end{array}$ \\
\hline constant & $\begin{array}{c}0.004 \\
(0.005)\end{array}$ & $\begin{array}{c}-16.372 * * * \\
(5.607)\end{array}$ & $\begin{array}{c}4.430 \\
(10.488)\end{array}$ & $\begin{array}{l}-58.953 * * * \\
(17.079)\end{array}$ & $\begin{array}{l}-25.578 * \\
(13.067)\end{array}$ & $\begin{array}{l}-104.998 \\
(123.067)\end{array}$ \\
\hline $\mathrm{N}$ & 466 & 466 & 109 & 114 & 123 & 120 \\
\hline Studies & 33 & 33 & 22 & 20 & 18 & 15 \\
\hline$R$-squared & 0.050 & 0.512 & 0.834 & 0.706 & 0.702 & 0.492 \\
\hline Adjusted $R$-squared & 0.048 & 0.490 & 0.805 & 0.657 & 0.654 & 0.419 \\
\hline $\mathrm{AIC}$ & -1747.543 & -2022.274 & -489.114 & -542.843 & -568.693 & $-6|7.96|$ \\
\hline $\mathrm{BIC}$ & -1739.254 & -1939.390 & -446.053 & -501.800 & -529.323 & -578.936 \\
\hline
\end{tabular}

Note: $\mathrm{AIC}=$ Akaike information criterion; $\mathrm{BIC}=$ Bayesian information criterion.

$* * *, * *$, and $*$ indicate significance at the $0.01,0.05$, and 0.10 levels, respectively. Robust standard errors are presented in parentheses. 
Table 5. Pooled Effect Size Based on Trim-and-Fill Analysis.

\begin{tabular}{|c|c|c|c|c|}
\hline Subgroup & Obs. & Effect Size (ES) & Lower $95 \% \mathrm{Cl}$ of $\mathrm{ES}$ & Upper $95 \% \mathrm{Cl}$ of ES \\
\hline Total & 466 & -0.037 & -0.048 & -0.027 \\
\hline geography $=$ Asia & 92 & -0.014 & -0.018 & -0.011 \\
\hline geography $=$ Europe & 149 & -0.012 & -0.034 & 0.010 \\
\hline geography = Global & 24 & -0.085 & -0.117 & -0.053 \\
\hline geography $=$ North America & 182 & -0.071 & -0.092 & -0.051 \\
\hline geography $=$ Africa & 19 & 0.008 & -0.018 & 0.034 \\
\hline class_hotel = all & 289 & -0.033 & -0.049 & -0.018 \\
\hline class_hotel = low-end & 46 & -0.050 & -0.068 & -0.031 \\
\hline class_hotel $=$ mid-scale & 44 & -0.030 & -0.054 & -0.006 \\
\hline class_hotel $=$ high-end & 87 & -0.047 & -0.073 & -0.021 \\
\hline$D V=A D R$ & 109 & -0.036 & -0.055 & -0.016 \\
\hline$D V=$ occupancy & 114 & -0.066 & -0.088 & -0.045 \\
\hline$D V=R e v P A R$ & 123 & -0.048 & -0.066 & -0.031 \\
\hline$D V=$ Others & 120 & 0.010 & -0.019 & 0.038 \\
\hline journal_article $=1$ & 253 & -0.069 & -0.087 & -0.052 \\
\hline journal_article $=0$ & 213 & -0.010 & -0.019 & 0.000 \\
\hline midyear $<=2013$ & 264 & -0.043 & -0.054 & -0.032 \\
\hline midyear $>2013$ & 202 & -0.029 & -0.049 & -0.009 \\
\hline
\end{tabular}

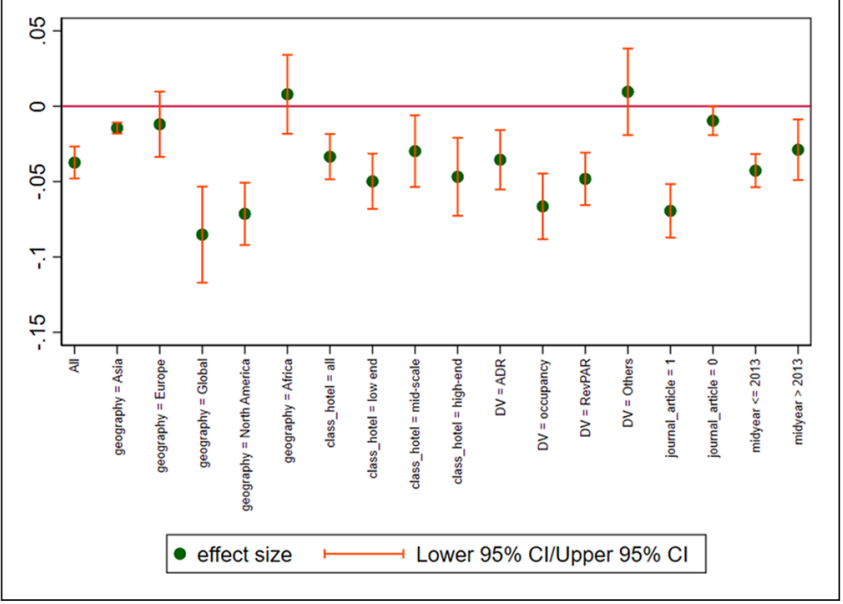

Figure 4. Combined effect sizes (partial correlation coefficients) for different subgroups.

covers a total of 466 estimates from 33 empirical studies. The model has an adjusted $R$ square of 0.49 . First, $S E(r)$ is still estimated to be negative and significant. Second, the coefficients of geography $=$ Europe and geography $=$ Africa are estimated to be statistically significant and positive. Since the average effect size is negative, the results show that the negative effect of Airbnb supply on hotel performance is less pronounced in European and African countries. Regarding the other categorical variable, the coefficient of class_hotel $=$ high-end is estimated to be positive and significant, suggesting that the strength of the negative effect of Airbnb is smaller for high-end hotels than low-end ones (class_hotel $=$ low-end, the reference group). Furthermore, none of the DV categories is estimated to be significant,

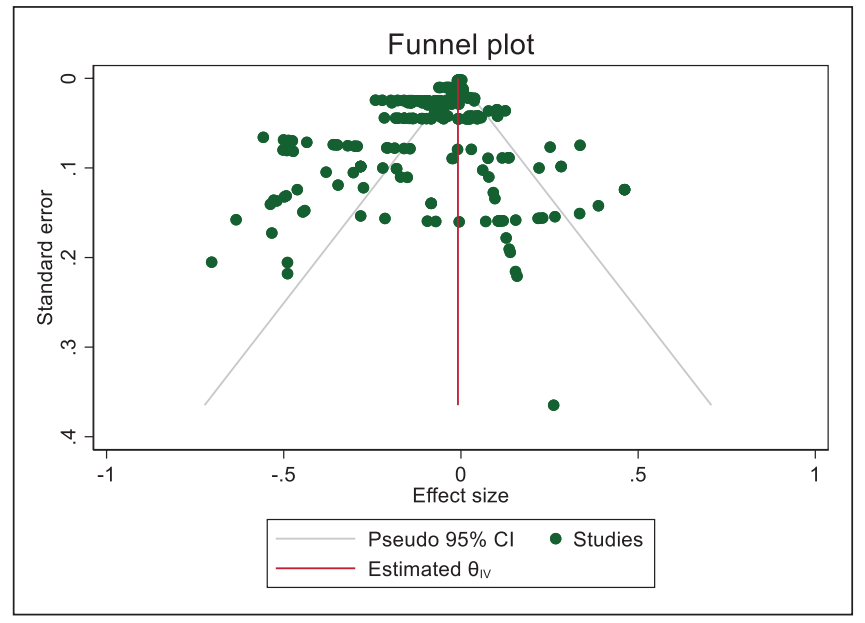

Figure 5. Funnel plot for publication bias analysis, journal article subsample.

indicating that the effect size does not vary significantly across different measures of hotel demand/performance after controlling for other factors. For other variables, timedummy, indep_lag and high frequency are estimated to be negative and significant, showing that adding the time-specific effects, using the lagged variable of Airbnb supply, and collecting high-frequency data leads to a more pronounced negative effect. More specifically, after including the time-specific effects, the effect size changes from an average of 0.00951 to -0.00337 , and after using the lagged variable, this effect size changes from -0.00174 to -0.0311 . The other variable, midyear, is estimated to be positive and significant. This result indicates that the negative effect of Airbnb decreases over time. 
Table 6. Meta-regression Results of Robustness Check.

\begin{tabular}{|c|c|c|c|c|}
\hline & Model 7 & Model 8 & Model 9 & Model 10 \\
\hline Variables & $\begin{array}{c}\text { All } \\
\text { WLS }\end{array}$ & $\begin{array}{c}\text { All } \\
\text { WLS }\end{array}$ & $\begin{array}{c}\text { All } \\
\text { WLS }\end{array}$ & $\begin{array}{l}\text { All } \\
\text { Logit }\end{array}$ \\
\hline$S E(r)$ & $\begin{array}{c}-1.785 * * \\
(0.821)\end{array}$ & $\begin{array}{l}-3.392 * * * \\
(0.911)\end{array}$ & $\begin{array}{c}-0.235 \\
(0.840)\end{array}$ & $\begin{array}{c}7.299 * \\
(4.130)\end{array}$ \\
\hline property_data & $\begin{array}{c}0.021 \\
(0.024)\end{array}$ & $\begin{array}{l}-0.001 \\
(0.022)\end{array}$ & $\begin{array}{l}0.459 * * * \\
(0.116)\end{array}$ & $\begin{array}{c}-0.762 \\
(0.814)\end{array}$ \\
\hline midyear & $\begin{array}{l}0.009 * * * \\
(0.003)\end{array}$ & $\begin{array}{l}0.008 * * * \\
(0.003)\end{array}$ & $\begin{array}{c}-0.000 \\
(0.003)\end{array}$ & $\begin{array}{c}0.097 \\
(0.091)\end{array}$ \\
\hline geography = Europe & $\begin{array}{l}0.062 * * \\
(0.029)\end{array}$ & $\begin{array}{l}0.060 * * \\
(0.025)\end{array}$ & $\begin{array}{c}-0.057 \\
(0.038)\end{array}$ & $\begin{array}{c}-0.301 \\
(0.563)\end{array}$ \\
\hline geography $=$ Global & $\begin{array}{c}0.018 \\
(0.049)\end{array}$ & $\begin{array}{c}0.047 \\
(0.05 I)\end{array}$ & $\begin{array}{l}0.069 * * \\
(0.030)\end{array}$ & $\begin{array}{c}0.466 \\
(0.835)\end{array}$ \\
\hline geography $=$ North America & $\begin{array}{c}0.039 \\
(0.024)\end{array}$ & $\begin{array}{c}0.010 \\
(0.022)\end{array}$ & $\begin{array}{l}0.042^{* *} \\
(0.018)\end{array}$ & $\begin{array}{l}-1.150 \\
(0.808)\end{array}$ \\
\hline geography $=$ Africa & $\begin{array}{c}0.053 \\
(0.036)\end{array}$ & $\begin{array}{l}0.072 * * \\
(0.029)\end{array}$ & $\begin{array}{c}-0.015 \\
(0.071)\end{array}$ & $\begin{array}{l}4.287 * * * \\
(1.215)\end{array}$ \\
\hline class_hotel = all & $\begin{array}{l}0.025^{* *} \\
(0.010)\end{array}$ & $\begin{array}{c}0.016 \\
(0.011)\end{array}$ & $\begin{array}{l}0.016 \\
(0.018)\end{array}$ & $\begin{array}{l}2.121 * * * \\
(0.797)\end{array}$ \\
\hline class_hotel $=$ mid-scale & $\begin{array}{c}-0.075 \\
(0.057)\end{array}$ & $\begin{array}{c}-0.022 \\
(0.036)\end{array}$ & $\begin{array}{c}0.010 \\
(0.024)\end{array}$ & $\begin{array}{l}2.216 * * \\
(0.963)\end{array}$ \\
\hline class_hotel $=$ high-end & $\begin{array}{l}0.020 * * * \\
(0.006)\end{array}$ & $\begin{array}{l}0.017^{* * *} \\
(0.006)\end{array}$ & $\begin{array}{c}0.011 \\
(0.014)\end{array}$ & $\begin{array}{l}2.354 * * * \\
(0.886)\end{array}$ \\
\hline robust_error & $\begin{array}{c}-0.040 \\
(0.024)\end{array}$ & $\begin{array}{c}-0.024 \\
(0.026)\end{array}$ & $\begin{array}{l}-0.36 I^{* *} \\
(0.124)\end{array}$ & $\begin{array}{c}-0.254 \\
(0.568)\end{array}$ \\
\hline log_log & $\begin{array}{c}-0.008 \\
(0.011)\end{array}$ & $\begin{array}{c}-0.007 \\
(0.011)\end{array}$ & $\begin{array}{c}-0.035 \\
(0.027)\end{array}$ & $\begin{array}{c}0.259 \\
(0.650)\end{array}$ \\
\hline Inindep & $\begin{array}{l}0.012 \\
(0.016)\end{array}$ & $\begin{array}{l}0.005 \\
(0.011)\end{array}$ & $\begin{array}{l}0.022 \\
(0.023)\end{array}$ & $\begin{array}{c}0.471 \\
(0.33 I)\end{array}$ \\
\hline timedummy & $\begin{array}{c}-0.006 \\
(0.012)\end{array}$ & $\begin{array}{l}-0.013^{* *} \\
(0.006)\end{array}$ & $\begin{array}{l}-0.077^{* * *} \\
(0.019)\end{array}$ & $\begin{array}{c}-1.475^{* *} \\
(0.665)\end{array}$ \\
\hline indep_lag & $\begin{array}{l}-0.050 * * \\
(0.018)\end{array}$ & $\begin{array}{l}-0.029 * * * \\
(0.011)\end{array}$ & $\begin{array}{l}-0.282^{* * *} \\
(0.096)\end{array}$ & $\begin{array}{l}-0.995^{* * * *} \\
(0.386)\end{array}$ \\
\hline$D V=$ occupancy & $\begin{array}{c}-0.017 \\
(0.016)\end{array}$ & $\begin{array}{l}-0.011 \\
(0.011)\end{array}$ & $\begin{array}{c}0.001 \\
(0.003)\end{array}$ & $\begin{array}{c}-0.926 \\
(0.670)\end{array}$ \\
\hline$D V=R e v P A R$ & $\begin{array}{c}-0.003 \\
(0.005)\end{array}$ & $\begin{array}{c}0.001 \\
(0.006)\end{array}$ & $\begin{array}{c}0.002 \\
(0.018)\end{array}$ & $\begin{array}{c}-0.729 \\
(0.681)\end{array}$ \\
\hline$D V=$ others & $\begin{array}{l}-0.006 \\
(0.008)\end{array}$ & $\begin{array}{c}-0.007 \\
(0.007)\end{array}$ & $\begin{array}{c}0.001 \\
(0.002)\end{array}$ & $\begin{array}{c}-0.203 \\
(0.606)\end{array}$ \\
\hline high_frequency & $\begin{array}{c}-0.036^{*} \\
(0.021)\end{array}$ & $\begin{array}{l}-0.038 * * \\
(0.018)\end{array}$ & $\begin{array}{l}-0.103 \\
(0.086)\end{array}$ & $\begin{array}{c}0.473 \\
(0.565)\end{array}$ \\
\hline journal_article & $\begin{array}{c}0.001 \\
(0.022)\end{array}$ & $\begin{array}{c}0.029 \\
(0.021)\end{array}$ & & $\begin{array}{l}-1.749 * * * \\
(0.627)\end{array}$ \\
\hline constant & $\begin{array}{c}-18.73 \mid * * * \\
(6.440)\end{array}$ & $\begin{array}{c}-16.344 * * * \\
(5.592)\end{array}$ & $\begin{array}{c}0.078 \\
(6.407)\end{array}$ & $\begin{array}{l}-196.962 \\
(181.977)\end{array}$ \\
\hline $\mathrm{N}$ & 466 & 465 & 253 & 466 \\
\hline Studies & 33 & 33 & 17 & 33 \\
\hline$R$-squared & 0.640 & 0.513 & 0.514 & \\
\hline Adjusted $R$-squared & 0.624 & 0.491 & 0.474 & \\
\hline $\mathrm{AIC}$ & -1920.834 & -2020.677 & -1306.874 & 470.051 \\
\hline $\mathrm{BIC}$ & -1842.095 & -1941.978 & -1253.873 & 548.790 \\
\hline
\end{tabular}

Note: $\mathrm{AIC}=$ Akaike information criterion; $\mathrm{BIC}=$ Bayesian information criterion.

$* * *, * *$, and $*$ indicate significance at the $0.01,0.05$, and 0.10 levels, respectively. Robust standard errors are presented in parentheses. 
We further run the meta-regression of effect sizes on four subsamples with different measures of hotel performance. Specifically, models 3 to 6 present the estimation results derived from those studies that estimate equations whose dependent variables are ADR, Occupancy, RevPAR, and Others, respectively. Note that each performance metric captures different angles of the relationship with the independent variables, so the results of the additional variables do not necessarily have to be homogeneous across these models. For example, ADR provides insights on the pricing strategy, occupancy shows the lodging demand related to room nights sold, and RevPAR takes into account both pricing and room nights sold.

As indicated by the adjusted $R$ square of models 3 to 5 , the overall goodness of fit is satisfactory. Model 3 (ADR) and model 5 (RevPAR) provide some coincident results in terms of estimates' significance and sign. In these two models, geography $=$ Global and geography $=$ North America are estimated to be positive, suggesting that the negative effects of Airbnb on hotel ADR and RevPAR are smaller using the global and North American sample (than the Asian sample). Likewise, as indicated by the positive and significant coefficient of class_hotel $=$ high-end, high-end hotels are less impacted by Airbnb supply, and this is particularly true for ADR. Some discrepancies can be recognized between the two models. Model 3 shows that the price of European hotels (geography $=$ Europe) is less impacted than its Asian counterparts, and the model with more independent variables (lnindep) yields a smaller negative effect on price. In contrast, the results of model 5 highlight the importance of research period (midyear), time effect specification (timedummy), and data frequency (high_frequency). In particular, adding time-specific effects helps estimate a more pronounced negative effect of Airbnb supply on hotel RevPAR. In model 4 of hotel occupancy, the significant and positive coefficient of midyear highlights the decaying negative effect of Airbnb supply on hotel occupancy over time. The result also highlights the importance of model specification in hotel occupancy models. For example, the negative and significant coefficient of robust_error suggests that the use of robust standard errors leads to a different estimate of the Airbnb supply effect. Also, the model functional form plays a role as indicated by the positive and significant coefficient of $\log \_\log$. Considering the magnitude of this coefficient, which is 0.205 , we find that the effect of functional form is substantial to dictate the effect size of Airbnb supply on hotel occupancy. Last, in model 6 for other dependent variable measures, only indep_lag is estimated to be significant. The negative coefficient indicates that the negative effect of Airbnb supply is stronger when the lagged effect was considered.

We further run several robustness checks on our results in Table 6. First, some studies in our data set include a large number of effect sizes reported, while others only include a few. We, therefore, use the frequency weight to make sure the total weights of observations from a single study sum up to one. Model 7 presents the results, and the only change is that the estimated coefficient of timedummy becomes statistically insignificant compared to model 2. Similar to model 2, the effect size is attenuated in the case of European hotels as well as when the sample consists of hotels in the high-end category. The results also confirm that the negative effect of Airbnb decreases over time (i.e., midyear coefficient is positive and significant). The results from model 7 , therefore, indicate that findings are robust. Second, we excluded the outliers if the absolute value of the DFBETA statistic is larger than one (Bollen and Jackman 1985). Only one observation of effect size was excluded, and the updated model 8 presents findings very similar to those of model 2 . Third, we estimate the model using the sample of journal articles only, and model 9 presents this result. While timedummy and indep_lag are still significant, the coefficient of midyear becomes insignificant. These results suggest that adding time-specific effects and including the lagged effect of the independent variable show a more pronounced effect of the Airbnb supply on hotel performance. However, in this subsample, the effect seems not to vary across research periods. The coefficient of property_data is statistically significant and positive. The magnitude of this coefficient underscores the importance of collecting property-level data. Moreover, $S E(r)$ was estimated to be insignificant. In Figure 5, a funnel plot of journal article subsample includes many points out of the inverted-funnel (pseudo 95\% CI) area, and the left-skewed asymmetric pattern indicates the presence of type I publication bias. Lastly, we run a logit regression by coding $r$ into a binary variable: positive $(y=$ $1)$ versus negative $(y=0)$. The results indicate that it is more likely to observe a positive effect size in studies using a sample of midscale and high-end hotels, specifying a nonlagged independent variable of Airbnb supply (indep_lag $=0$ ), without time-specific effects (timedummy $=0$ ), and not published in refereed journals (journal_article $=0$ ).

\section{Conclusion}

\section{Discussion}

P2P accommodation platforms like Airbnb constitute a viable alternative to traditional hotel booking for many consumers. The substitution patterns between the two business models have been widely investigated in academia. Extant studies provide mixed results, with the majority of works reporting a negative effect of Airbnb supply on hotel performance (e.g., Chang and Sokol 2020; Dogru, Hanks, Mody, et al. 2020; Dogru, Hanks, Ozdemir, et al. 2020; Xie and Kwok 2017). Stemming from this, the present study investigates the possible presence of publication bias (Stanley and Doucouliagos 2012) and reveals a preference for publishing studies that report a negative impact. The smaller combined effect size in nonjournal articles suggests that positive and 
nonsignificant effects are more likely to be found in research published in other outlets, such as conference papers and working papers, which receive less scrutiny from editors and reviewers.

To determine the actual effect size, the study relies on 466 estimates from 33 published and unpublished studies. A metaanalysis finds evidence that the overall effect size is negative but marginal, ranging between -0.036 and -0.066 (impact on ADR and occupancy, respectively). The effect size is stronger $(-0.066)$ when using occupancy as the indicator of hotel performance. This result reflects that the detrimental effect of an increase of Airbnb supply is more noticeable when studies use occupancy measures compared to integrated measures of performance that consider both occupancy and ADR. We conclude that despite hotel occupancy being harmed by the increase of Airbnb units, hotel revenues are affected to a lesser extent. A possible explanation might be that the substitution effect is more likely to occur with low-rate hotel rooms. This finding is in line with the stronger negative effect of Airbnb on low-end hotels' performance. Our analysis also reveals that the combined negative effect size is slightly stronger in studies that focus on an early research period (midyear $\leq 2013$ ) compared to those that consider a later one. This result suggests that hotels are becoming more resilient to the increase in rentals supply over time.

In Tables 4 and 6 , we presented the specific boundary conditions for the effects. Model 2, which includes all the dependent variables from the 33 studies in the sample, reveals interesting findings. The effect size varies across continents. When looking at different geographical areas, the results suggest that the overall effect is less pronounced in Europe compared to Asia. European countries own a large number of independent hotels that are not affiliated with any chains, and these hotels can better customize their service to better serve the local customers and provide more authentical experiences. Therefore, Airbnb became less substitutable to hotels' products, leaving a diminished negative effect of Airbnb supply on hotel performance there. The findings also reveal that the negative effect is less salient for high-end hotels (vs. low-end). This finding is in line with the results from previous studies (Zervas, Proserpio, and Byers 2017; Chang and Sokol 2020) and suggests that low-end hotels are more vulnerable to the rise of Airbnb. This result also emerges from model 5, which includes studies considering RevPAR as the indicator of performance. These findings might imply that low-end hotels should strengthen their differentiation from accommodation rentals to become resilient to the competition of Airbnb.

Additionally, the study finds that some model specification factors affect the effect size. The negative effect is more salient as the model includes the time-specific effect. When the analysis uses robust standard errors for model estimation, the negative effect on hotel occupancy is more pronounced. Finally, when the models use the lagged variable of Airbnb supply, the effect is also larger. This result may suggest the presence of intertemporal effects of Airbnb supply; that is, hotel performance in the current period is also a function of Airbnb supply in previous periods.

\section{Theoretical and Practical Implications}

The study has two clear theoretical implications. First, it unveils the actual aggregate impact of Airbnb supply on hotel performance. To date, most of the studies in the field have used location-specific data. Our work instead provides a more comprehensive picture for the effect. Specifically, the meta-analysis quantifies a marginal and negative effect that contradicts a number of previous empirical studies that are restricted to a specific country or set of countries (e.g., Dogru, Hanks, Mody, et al. 2020; Dogru, Hanks, Ozdemir, et al. 2020; Zervas, Proserpio, and Byers 2017; Xie and Kwok 2017). While Airbnb listings in cities like New York seem to be substitutes for traditional hotel accommodation (Gunter, Önder, and Zekan 2020), our findings provide evidence that this substitution pattern does not translate into a notable decrease in hotel performance. Indeed, our estimates suggest that the overall effect of Airbnb supply on hotel performance is negative but very small. As such, the study advances our understanding of the interplay between Airbnb supply and hotel performance. Second, the study reveals that model specification settings (e.g., the use of robust standard errors or not) play a critical role in determining the effect size. Building on this evidence, we recommend the specification of time-specific effects to the panel data model, the use of robust standard errors, and the inclusion of more area/ location-specific independent variables into the empirical model. These recommendations could be generalizable to other econometric endeavors in tourism.

Additionally, our findings have clear implications for practitioners and policymakers. Our study unveils a marginal substitution of hotel demand by the growth of accommodation rentals in the case of low-end hotels. This substitution trend might increase over time unless low-end hotels' managers find effective ways to enhance their competitiveness in the market. In fact, Airbnb - compared with the traditional hospitality - benefits from a positive reviewing bias (Osman et al. 2019), an enhanced human connection with hosts (Ert and Fleischer 2020), and opportunities for cocreation of experiences (Buhalis, Andreu, and Gnoth 2020). To face these threats, the traditional hospitality could consider strategic actions such as the provision of extended services (e.g., offering personalized experiences through partnerships with local independent businesses) or investment in marketing capabilities (Revilla-Camacho et al. 2020) and product development (e.g., extending the range of facilities to accommodate emerging guests' needs).

The study provides actionable policy suggestions. While Airbnb supply increases employment and generates income and taxes at the destination (Dogru, Mody, Line, et al. 2020), its growth often leads to instability in the short-term rental 
market. This is the first study that synthesizes the literature on the effects of Airbnb supply on hotel performance and presents the overall effect by geographic area. Local authorities in geographic areas with high penetration of $\mathrm{P} 2 \mathrm{P}$ accommodation rentals (e.g., North America) might be able to exploit this source of income more effectively by regulating this market (Nieuwland and Van Melik 2020). For instance, Vinogradov, Leick, and Kivedal (2020) suggest that no regulation of P2P rentals will lead to an uneven growth pattern and highlight the benefits of moderate taxation.

\section{Limitations and Future Research Agenda}

Our study is not without limitations. First, the findings emerge from a set of works that only consider one P2P accommodation platform (i.e., Airbnb). While properties listed on Airbnb represent the main source of $\mathrm{P} 2 \mathrm{P}$ accommodation supply, additional holiday rental platforms like Homeaway also operate in this marketplace. Second, because of the limited sample size for meta-analysis, we are unable to scrutinize some additional factors in the meta-regression, such as the specific type of control variables in the model and chain hotel affiliation. Importantly, independent hotels can use revenue management tools (Abrate, Nicolau, and Viglia 2019; Abrate and Viglia 2016) to react to these different sources of competition and boost their revenues. Third, we recognize the heterogeneous nature of the data and, even though we have tried to address this issue to the fullest extent by accounting for a comprehensive set of factors in the analysis, the variability of the $\mathrm{P} 2 \mathrm{P}$ phenomenon is a limitation because total control is not attainable. Fourth, owing to the limited sample size of publications from well-reputed journals, we were unable to limit our metaanalysis to this specific subsample. Last, the accommodation sector is witnessing a great dynamism, with new P2P catering to the increasing demand for unique accommodation (Wang, Asaad, and Filieri 2020) and different tourism flows (Ribaudo and Figini 2017). It is worth noting that the whole sector may also face a temporary swift decrease in demand instigated by the global pandemic (COVID-19). Together with the professionalization of the sector, these trends will shape the future interplay of $\mathrm{P} 2 \mathrm{P}$ and traditional accommodation (Dolnicar and Zare 2020), with full flat options preferred to shared flats (Bresciani et al. 2021). Acknowledging this, our study paves the way for innovative multilevel metaanalytic approaches (Maseeh et al. 2021) on the impact of Airbnb on hotel performance. 







\section{Declaration of Conflicting Interests}

The author(s) declared no potential conflicts of interest with respect to the research, authorship, and/or publication of this article.

\section{Funding}

The author(s) received no financial support for the research, authorship, and/or publication of this article.

\section{ORCID iDs}

Giampaolo Viglia (iD https://orcid.org/0000-0001-8521-4988

Juan Luis Nicolau iD https://orcid.org/0000-0003-0048-2823

\section{References}

Abrate, Graziano, Juan Luis Nicolau, and Giampaolo Viglia. 2019. "The Impact of Dynamic Price Variability on Revenue Maximization." Tourism Management 74:224-33.

Abrate, Graziano, and Giampaolo Viglia. 2016. "Strategic and Tactical Price Decisions in Hotel Revenue Management." Tourism Management 55:123-32.

Airbnb. 2020a. About us. https://news.airbnb.com/about-us/.

Airbnb. 2020b. Airbnb's Growth and Summer Travel Updates. https://news.airbnb.com/airbnbs-growth-and-summer-travelupdates/.

Apergis, Nicholas, Tasawar Hayat, and Tareq Saeed. 2020. “Airbnb and Hotel Revenues in Popular Greek Destinations." Journal of Economic Studies 48 (4): 804-16.

Aznar, Juan Pedro, Josep M. Sayeras, Alba Rocafort, and Jorge Galiana. 2017. "The Irruption of Airbnb and Its Effects on Hotel Profitability: An Analysis of Barcelona's Hotel Sector." Intangible Capital 13 (1): 147-59.

Bardhi, Fleura, and Giana M. Eckhardt. 2012. "Access-Based Consumption: The Case of Car Sharing." Journal of Consumer Research 39 (4): 881-98.

Bellemare, Marc F., Takaaki Masaki, and Thomas B. Pepinsky. 2017. "Lagged Explanatory Variables and the Estimation of Causal Effect." Journal of Politics 79 (3): 949-63.

Benítez-Aurioles, Beatriz. 2019. "Is Airbnb Bad for Hotels?" Current Issues in Tourism 1-4.

Benítez-Aurioles, Beatriz. 2020. "Impacts of the Peer-to-Peer Market on Tourist Accommodation on the Balearic Islands of Mallorca and Menorca." Island Studies Journal 15 (2): 353-70.

Bollen, Kenneth A., and Robert W. Jackman. 1985. "Regression Diagnostics: An Expository Treatment of Outliers and Influential Cases." Sociological Methods \& Research 13 (4): $510-42$.

Borysiewicz, R. F. 2017. “Airbnb Spatial Agglomeration and Hotel Prices: Case of Palma de Mallorca." Universitat de les Illes Balears.

Botsman, R. 2014. "Sharing's Not Just for Start-Ups." Harvard Business Review 92 (9): 23-25.

Bostman, R., and Roo Rogers. 2011. What's Mine Is Yours. How Collaborative Consumption Is Changing the Way We Live. London: Collins.

Bresciani, Stefano, Alberto Ferraris, Gabriele Santoro, Katia Premazzi, Roberto Quaglia, Dorra Yahiaoui, and Giampaolo Viglia. "The Seven Lives of Airbnb. The Role of Accommodation Types." Annals of Tourism Research 88 (2021): 103170.
Breyne, Louis, and Louis Horé. 2020. Airbnb Impact on the Hotel Market in Brussels. Louvain School of Management, Université catholique de Louvain.

Buhalis, D., L. Andreu, and J. Gnoth. 2020. "The Dark Side of the Sharing Economy: Balancing Value Co-creation and Value Co-destruction." Psychology \& Marketing 37 (5): 689-704.

Buhalis, Dimitrios, Tracy Harwood, Vanja Bogicevic, Giampaolo Viglia, Srikanth Beldona, and Charles Hofacker. 2019. "Technological Disruptions in Services: Lessons from Tourism and Hospitality." Journal of Service Management 30 (4): 484-506.

Byers, John W., Flavio Esposito, Davide Proserpio, and Georgios Zervas. 2013. "The Hyper-local Economic Impact of Airbnb." Paper presented at: 9th Symposium on Statistical Challenges in eCommerce Research; Lisbon, Portugal.

Chang, Hung-Hao, and D. Daniel Sokol. 2020. "How Incumbents Respond to Competition from Innovative Disruptors in the Sharing Economy-The Impact of Airbnb on Hotel Performance." Strategic Management Journal. https://doi. org/10.1002/smj.3201.

Chen, Wei, Zaiyan Wei, and Karen Xie. 2019. "Regulating Professional Players in Peer-to-Peer Markets: Evidence from Airbnb." SSRN 3450793.

Cheng, Mingming, and Guojie Zhang. 2019. "When Western Hosts Meet Eastern Guests: Airbnb Hosts' Experience with Chinese Outbound Tourists." Annals of Tourism Research 75:288-303.

Choi, K. Hong, Joohyun Jung, S. Yeol Ryu, Su-Do Kim, and S. Min Yoon. 2015. "The Relationship between Airbnb and the Hotel Revenue: In the Case of Korea." Indian Journal of Science and Technology 8 (26): 1-8.

Coyle, Diane, and Timothy Yeung. 2016. "Understanding AirBnB in fourteen European Cities." Jean-Jacques Laffont Digital Chair Working Papers 7088:1-33.

Djankov, Simeon, and Peter Murrell. 2002. "Enterprise Restructuring in Transition: A Quantitative Survey." Journal of Economic Literature 40 (3): 739-92.

Dogru, Tarik, Makarand Mody, and Courtney Suess. 2017 "The Hotel Industry's Achilles Heel? Quantifying the Negative Impacts of Airbnb on Boston's Hotel Performance." Boston Hospitality Review 5 (3): 1-11.

Dogru, Tarik, Lydia Hanks, Makarand Mody, Courtney Suess, and Ercan Sirakaya-Turk. 2020. "The Effects of Airbnb on Hotel Performance: Evidence from Cities beyond the United States." Tourism Management 79:104090.

Dogru, Tarik, Lydia Hanks, Ozgur Ozdemir, Murat Kizildag, Apostolos Ampountolas, and Ilhan Demirer. 2020. "Does Airbnb Have a Homogenous Impact? Examining Airbnb's Effect on Hotels with Different Organizational Structures." International Journal of Hospitality Management 86:102451.

Dogru, Tarik, Makarand Mody, and Courtney Suess. 2019. "Adding Evidence to the Debate: Quantifying Airbnb's Disruptive Impact on Ten Key Hotel Markets." Tourism Management 72:27-38.

Dogru, Tarik, Makarand Mody, Nathan Line, Courtney Suess, Lydia Hanks, and Mark Bonn. 2020. "Investigating the Whole Picture: Comparing the Effects of Airbnb Supply and Hotel Supply on Hotel Performance across the United States." Tourism Management 79:104094.

Dogru, Tarik, Makarand Mody, Courtney Suess, Sean McGinley, and Nathaniel D. Line. 2020. "The Airbnb Paradox: Positive 
Employment Effects in the Hospitality Industry." Tourism Management 77:104001.

Dolnicar, Sara. 2018. "Unique Features of Peer-to-Peer Accommodation Networks." In Peer-to-Peer Accommodation Networks: Pushing the Boundaries, 1-14. Oxford: Good fellow.

Dolnicar, Sara. 2019. "A Review of Research into Paid Online Peer-to-Peer Accommodation: Launching the Annals of Tourism Research Curated Collection on Peer-to-Peer Accommodation." Annals of Tourism Research 75:248-64.

Dolnicar, Sara, and Samira Zare. 2020. "COVID19 and AirbnbDisrupting the Disruptor." Annals of Tourism Research 83:102961.

Doucouliagos, Hristos Chris. 2011. "How Large Is Large? Preliminary and Relative Guidelines for Interpreting Partial Correlations in Economics (No. 2011_5).” Deakin University, Faculty of Business and Law, School of Accounting, Economics and Finance.

Duval, Sue, and Richard Tweedie. 2000. "Trim and Fill: A Simple Funnel-Plot-Based Method of Testing and Adjusting for Publication Bias in Meta-analysis." Biometrics 56 (2): 455-63.

Ert, Eyal, and Aliza Fleischer. 2020. "What Do Airbnb Hosts Reveal by Posting Photographs Online and How Does It Affect Their Perceived Trustworthiness?" Psychology \& Marketing 37 (5): 630-40.

Falk, Martin Thomas, and Yang Yang. 2020. "Hotels Benefit from Stricter Regulations on Short-Term Rentals in European Cities." Tourism Economics. April 21.

Farronato, Chiara, and Andrey Fradkin. 2018. "The Welfare Effects of Peer Entry in the Accommodation Market: The Case of Airbnb." No. w24361. Washington, DC: National Bureau of Economic Research.

Ferguson, Christopher J., and Michael T. Brannick. 2012. "Publication Bias in Psychological Science: Prevalence, Methods for Identifying and Controlling, and Implications for the Use of Meta-analyses." Psychological Methods 17 (1): 120.

Gerwe, Oksana, and Rosario Silva Froján. 2017. "Airbnb: A Foe or a Friend? Effect of Entry of a Peer-to-Peer Platform on Incumbents' Performance." In Academy of Management Proceedings, 1, 13347. Briarcliff Manor, NY: Academy of Management.

Gibbs, Chris, Daniel Guttentag, Ulrike Gretzel, Lan Yao, and Jym Morton. 2018. "Use of Dynamic Pricing Strategies by Airbnb Hosts." International Journal of Contemporary Hospitality Management 20 (1): 2-20.

Ginindza, Sebenzile, and Tembi Maloney Tichaawa. 2019. “The Impact of Sharing Accommodation on the Hotel Occupancy Rate in the Kingdom of Swaziland." Current Issues in Tourism 22 (16): 1975-91.

Glass, Gene V. 1976. "Primary, Secondary, and Meta-analysis of Research." Educational Researcher 5 (10): 3-8.

Greenberg, David H., Charles Michalopoulos, and Philip K. Robins. 2003. "A Meta-analysis of Government-Sponsored Training Programs." ILR Review 57 (1): 31-53.

Gunter, Ulrich, and Irem Önder. 2018. "Determinants of Airbnb Demand in Vienna and Their Implications for the Traditional Accommodation Industry.” Tourism Economics 24 (3): 270-93.

Gunter, U., Önder I., and Bozana Zekan. 2020. "Modeling Airbnb Demand to New York City While Employing Spatial Panel Data at the Listing Level.” Tourism Management 77:104000.
Gutiérrez, Javier, Juan Carlos García-Palomares, Gustavo Romanillos, and María Henar Salas-Olmedo. 2017. "The Eruption of Airbnb in Tourist Cities: Comparing Spatial Patterns of Hotels and Peer-to-Peer Accommodation in Barcelona." Tourism Management 62:278-91.

Guttentag, Daniel, Stephen Smith, Luke Potwarka, and Mark Havitz. 2018. "Why Tourists Choose Airbnb: A Motivation-Based Segmentation Study." Journal of Travel Research 57 (3): 342-59.

Havranek, Tomas, Zuzana Irsova, and Olesia Zeynalova. 2018. "Tuition Fees and University Enrolment: A Meta-regression Analysis." Oxford Bulletin of Economics and Statistics 80 (6): $1145-84$

Heo, Cindy Yoonjoung, Inès Blal, and Miju Choi. 2019. "What Is Happening in Paris? Airbnb, Hotels, and the Parisian Market: A Case Study." Tourism Management 70:78-88.

Hooijer, Puck. 2016. "The Relationship between Airbnb and the Hotel Revenue: Evidence from the Netherlands." University of Amsterdam Dissertation.

Karlsson, Logi, and Sara Dolnicar. 2016. "Someone's Been Sleeping in My Bed.” Annals of Tourism Research 58:159-62.

Karlsson, Logi, Astrid Kemperman, and Sara Dolnicar. 2017. "May I Sleep in Your Bed? Getting Permission to Book." Annals of Tourism Research 62:1-12.

Kim, Min Jung, and Hwa Ryung Lee. 2019. "The Airbnb Effect on the Hotel Industry: Evidence from Korea." Working Paper 2019-01. Korea Development Institute.

Kuo, Fang-Chang, and Hsin-Hsi Shih. 2020. "The Impact of Sharing Economy: Evidence from Airbnb and Taiwanese Hotel Industry." SSRN. https://ssrn.com/abstract=3622098.

Lee, Seunghwan, and Dae-Young Kim. 2018. "The Effect of Hedonic and Utilitarian Values on Satisfaction and Loyalty of Airbnb Users." International Journal of Contemporary Hospitality Management 30 (3): 1332-51.

Leoni, Veronica, Paolo Figini, and Jan Olof William Nilsson. 2020. "It's Not All about Price. The Determinants of Occupancy Rates in Peer-to-Peer Accommodation: A Methodological Contribution." International Journal of Contemporary Hospitality Management 32 (4): 1693-711.

Magaš, Damir, and Zrinka Zadel. 2020. "Influence of Airbnb on Hotel Sector Performance Indicators in Croatia." In Faculty of Tourism and Hospitality Management in Opatija. Biennial International Congress, 147-61. Faculty of Tourism \& Hospitality Management, University of Rijeka.

Mao, Yifei, Xuan Tian, and Kailei Ye. 2019. "Real Effects of Peer-to-Peer Rental: Evidence from Airbnb.” Kelley School of Business Research Paper 18-15: 19-13.

Maseeh, Haroon Iqbal, Charles Jebarajakirthy, Robin Pentecost, Denni Arli, Scott Weaven, and Md Ashaduzzaman. 2021. "Privacy Concerns in E-commerce: A Multilevel Metaanalysis." Psychology \& Marketing 38 (10): 1779-98.

Mattila, Anna S. 2007. "The Impact of Affective Commitment and Hotel Type in Influencing Guests' Share of Wallet.” Journal of Hospitality \& Leisure Marketing 15 (4): 55-68.

McGowan, Richard, and John Mahon. 2018. "David versus Goliath: Airbnb and the New York Hotel Industry." Archives of Business Research 6 (4): 130-42.

Melo, Patricia C., Daniel J. Graham, and Robert B. Noland. 2009. "A Meta-analysis of Estimates of Urban Agglomeration Economies." Regional Science and Urban Economics 39 (3): 332-42. 
Mhlanga, Oswald. 2021. "Airbnb and Hotels: Friends, Enemies or Frenemies?" International Journal of Culture, Tourism and Hospitality Research 15 (2): 202-17.

Mody, Makarand, Courtney Suess, and Xinran Lehto. 2019. "Going Back to Its Roots: Can Hospitableness Provide Hotels Competitive Advantage over the Sharing Economy?" International Journal of Hospitality Management 76:286-98.

Mohamad, Hassan. 2016. "Estimating the Impact of Airbnb on Hotels in Toronto." Master's thesis, Massachusetts Institute of Technology.

Moldes, Olaya, and Lisbeth Ku. 2020. "Materialistic Cues Make Us Miserable: A Meta-analysis of the Experimental Evidence for the Effects of Materialism on Individual and Societal WellBeing." Psychology \& Marketing 37 (10): 1396-419.

Neeser, David, Martin Peitz, and Jan Stuhler. 2015. "Does Airbnb Hurt Hotel Business: Evidence from the Nordic Countries." Universidad Carlos III de Madrid: 1-26.

Nguyen, Tai. 2019. "Home Sharing in New York City: Impact on Hotel, Rental, and Welfare." Dissertation, Department of Economics, Haverford College.

Nieto García, Marta, Pablo A. Muñoz-Gallego, Giampaolo Viglia, and Óscar González-Benito. 2019. "Be Social! The Impact of Self-Presentation on Peer-to-Peer Accommodation Revenue." Journal of Travel Research 59 (7): 1268-81.

Nieuwland, Shirley, and Rianne Van Melik. 2020. "Regulating Airbnb: How Cities Deal with Perceived Negative Externalities of ShortTerm Rentals." Current Issues in Tourism 23 (7): 811-25.

Nunkoo, Robin, Boopen Seetanah, Zameelah Rifkha Khan Jaffur, Paul George Warren Moraghen, and Raja Vinesh Sannassee. 2020. "Tourism and Economic Growth: A Meta-regression Analysis." Journal of Travel Research 59 (3): 404-23.

Osman, Hanaa, David D'Acunto, and Nick Johns. "Home and Away: Why Do Consumers Shy Away from Reporting Negative Experiences in the Peer-to-Peer Realms?" Psychology \& Marketing 2019; 36 (12): 1162-75.

Peng, B., H. Song, G. I. Crouch, and S. F. Witt. 2015. "A Metaanalysis of International Tourism Demand Elasticities." Journal of Travel Research 54 (5): 611-33.

Pera, Rebecca, Giampaolo Viglia, Laura Grazzini, and Daniele Dalli. 2019. "When Empathy Prevents Negative Reviewing Behavior." Annals of Tourism Research 75:265-78.

Revilla-Camacho, M. Á., B. Palacios-Florencio, D. Garzón, and C. Prado-Román. 2020. "Marketing Capabilities and Innovation. How Do They Affect the Financial Results of Hotels?" Psychology \& Marketing 37 (3): 506-18.

Rhee, Hosung Timothy, and Sung-Byung Yang. 2015. "Does Hotel Attribute Importance Differ by Hotel? Focusing on Hotel StarClassifications and Customers' Overall Ratings." Computers in Human Behavior 50:576-87.

Ribaudo, Giorgio, and Paolo Figini. 2017. "The Puzzle of Tourism Demand at Destinations Hosting UNESCO World Heritage Sites: An Analysis of Tourism Flows for Italy." Journal of Travel Research 56 (4): 521-42.

Ringquist, Evan. 2013. Meta-Analysis for Public Management and Policy. New York: John Wiley.

Roma, Paolo, Umberto Panniello, and Giovanna Lo Nigro. 2019. "Sharing Economy and Incumbents' Pricing Strategy: The Impact of Airbnb on the Hospitality Industry." International Journal of Production Economics 214:17-29.
Schmidt, Frank L., and John E. Hunter. 2014. Methods of MetaAnalysis: Correcting Error and Bias in Research Findings. Thousand Oaks, CA: Sage.

Schulze, Ralf. 2004. Meta-analysis-A Comparison of Approaches. Gottingen: Hogrefe.

Seo, Kwanglim, and Jungtae Soh. 2019. "An Analysis of the Impact of Airbnb on Hotel Performance: The Influence of Price Differences." Proceedings of The 2019 Pan Asia International Tourism Conference, Daejeon, Korea.

Shuqair, Saleh, Diego Costa Pinto, and Anna S. Mattila. 2019. "Benefits of Authenticity: Post-failure Loyalty in the Sharing Economy." Annals of Tourism Research 78:102741.

So, Kevin Kam Fung, Haemoon Oh, and Somang Min. 2018. "Motivations and Constraints of Airbnb Consumers: Findings from a Mixed-Methods Approach." Tourism Management 67:224-36.

Stanley, T. D. 2005. "Beyond Publication Bias." Journal of Economic Surveys 19 (3): 309-45.

Stanley, T. D., and Hristos Doucouliagos. 2010. "Picture This: A Simple Graph That Reveals Much Ado about Research." Journal of Economic Surveys 24 (1): 170-91.

Stanley, T. D., and Hristos Doucouliagos. 2012. Meta-Regression Analysis in Economics and Business. London: Routledge.

Stanley, T. D., and Hristos Doucouliagos. 2016. "Neither Fixed nor Random: Weighted Least Squares Meta-regression." Research Synthesis Methods 8 (1): 19-42.

Stanley, T. D., Hristos Doucouliagos, and Piers Steel. 2018. "Does ICT Generate Economic Growth? A Meta-regression Analysis." Journal of Economic Surveys 32 (3): 705-26.

Strømmen-Bakhtiar, Abbas, and Evgueni Vinogradov. 2019. "The Effects of Airbnb on Hotels in Norway." Society and Economy 41 (1): 87-105.

Tussyadiah, Iis P. 2016. "Factors of Satisfaction and Intention to Use Peer-to-Peer Accommodation." International Journal of Hospitality Management 55:70-80.

Van Houwelingen, Hans C., Lidia R. Arends, and Theo Stijnen. 2002. "Advanced Methods in Meta-analysis: Multivariate Approach and Meta-regression." Statistics in Medicine 21 (4): 589-624.

Vinogradov, Evgueni, Birgit Leick, and Bjørnar Karlsen Kivedal. 2020. "An Agent-Based Modelling Approach to Housing Market Regulations and Airbnb-Induced Tourism." Tourism Management 77:104004.

Volgger, Michael, Ross Taplin, and Christof Pforr. 2019. "The Evolution of 'Airbnb-Tourism': Demand-Side Dynamics around International Use of Peer-to-Peer Accommodation in Australia." Annals of Tourism Research 75:322-37.

Wang, Siyu. 2017. "The Impact of Airbnb on the Coachella Valley Hotel Industry." CMC Senior Theses. 1610. https://scholarship.claremont.edu/cmc_theses/1610.

Wang, Yichuan, Yousra Asaad, and Raffaele Filieri. 2020. "What Makes Hosts Trust Airbnb? Antecedents of Hosts' Trust toward Airbnb and Its Impact on Continuance Intention." Journal of Travel Research 59 (4): 686-703.

Xiang, Yixiao, and Sara Dolnicar. 2018. "Chapter 13-Networks in China." In Peer-to-Peer Accommodation Networks: Pushing the Boundaries, edited by S. Dolnicar. Oxford: Goodfellow.

Xie, Karen L., and Linchi Kwok. 2017. "The Effects of Airbnb's Price Positioning on Hotel Performance." International Journal of Hospitality Management 67:174-84. 
Yang, Yang, and Zhenxing Mao. 2019. "Welcome to My Home! An Empirical Analysis of Airbnb Supply in US Cities." Journal of Travel Research 58 (8): 1274-87.

Yang, Yang, and Zhenxing Mao. 2020. "Location Advantages of Lodging Properties: A Comparison between Hotels and Airbnb Units in an Urban Environment." Annals of Tourism Research 81:102861.

Yang, Yang, Lan Xue, and Thomas E. Jones. 2019. "TourismEnhancing Effect of World Heritage Sites: Panacea or Placebo? A Meta-analysis." Annals of Tourism Research 75:29-41.

Yang, Yang, Karen Pei-Sze Tan, Xiang (Robert) Li. 2019. "Antecedents and Consequences of Home-sharing Stays: Evidence from A Nationwide Household Tourism Survey." Tourism Management 70:15-28.

You, Ya, Gautham G. Vadakkepatt, and Amit M. Joshi. 2015. "A Meta-analysis of Electronic Word-of-Mouth Elasticity." Journal of Marketing 79 (2): 19-39.

Ytreberg, Nora Svarstad. 2016. "Competitive Effects of Airbnb on the Norwegian Hotel Market.” MS thesis, University of Bergen.

Zervas, Georgios, Davide Proserpio, and John W. Byers. 2017. "The Rise of the Sharing Economy: Estimating the Impact of Airbnb on the Hotel Industry." Journal of Marketing Research 54 (5): 687-705.

\section{Author Biographies}

Yang Yang, Ph.D., is Associate Professor, Department of Tourism and Hospitality Management, Temple University, USA. Email: yangy@temple.edu. His research interests include tourism economics and tourism geographies.

Marta Nieto Garcia, Ph.D., is a Senior Lecturer in Marketing at the University of Portsmouth, UK. Her research interests include pricing, eWOM and consumer decision-making. Specifically, she investigates the role of online information in shaping consumer responses.

Giampaolo Viglia, Ph.D., is Full Professor of Marketing. He is affiliated at the University of Portsmouth, UK, and at the University of Aosta Valley, Italy. His work revolves around service marketing, tourism, and hospitality management.

Juan L. Nicolau, Ph.D., is the J. Williard and Alice S. Marriott Professor of Revenue Management, Department of Hospitality and Tourism Management, Pamplin College of Business, Virginia Tech, USA. His research interests revolve around consumer choice and firm value. 